\title{
New Geological and Structural Facts under the Lateritic Cover in Garga Sarali, Ndokayo (East Cameroon) Area, from Audiomagnetotellurics Soundings
}

\author{
Pepogo Man-mvele Augustin Didier ${ }^{(D)},{ }^{1,2}$ \\ Ndougsa-Mbarga Théophile $\mathbb{D}^{2,3}$ Meying Arsène $\mathbb{D}^{2},{ }^{4}$ Ngoh Jean Daniel, ${ }^{2}$ \\ Mvondo-Ondoua Joseph, ${ }^{1}$ and Ngoumou Paul Claude ${ }^{3}$ \\ ${ }^{1}$ Department of Earth Sciences, Faculty of Sciences, University of Yaoundé I, P.O. Box 812, Yaoundé, Cameroon \\ ${ }^{2}$ Postgraduate School of Science, Technologies \& Geosciences, University of Yaoundé I, P.O. Box 812, Yaoundé, Cameroon \\ ${ }^{3}$ Department of Physics, Advanced Teacher's Training College, University of Yaoundé I, P.O. Box 47, Yaoundé, Cameroon \\ ${ }^{4}$ School of Geology and Mining and Engineering, University of Ngaoundéré, Ngaoundéré, Cameroon
}

Correspondence should be addressed to Pepogo Man-mvele Augustin Didier; augustin.pepogo@hotmail.com and Ndougsa-Mbarga Théophile; tndougsa@yahoo.fr

Received 28 August 2017; Revised 3 December 2017; Accepted 14 January 2018; Published 22 March 2018

Academic Editor: Yun-tai Chen

Copyright (c) 2018 Pepogo Man-mvele Augustin Didier et al. This is an open access article distributed under the Creative Commons Attribution License, which permits unrestricted use, distribution, and reproduction in any medium, provided the original work is properly cited.

\begin{abstract}
New geological and structural facts have been identified under the auriferous lateritic cover in Garga Sarali, Ndokayo area. Data were collected using AMT receiver system with frequencies ranging from $20 \mathrm{~Hz}$ to $50000 \mathrm{~Hz}$. It consists of 16 AMT stations along 03 profiles, over Pan-African formations of East Cameroon. The wide frequency range enabled us to probe deep into the subsurface to obtain necessary information. Using Imagem software, coherency of data has been evaluated and only the data with a coherency below or equal to 0.7 have been considered. Two programs were used to map the subsurface. The pseudosections were obtained using IPI2WIN-MT, while geoelectrical sections were obtained using Stratagem Resistivity Plotter. Analysis of the curves of dimensionality tests shows that there is not always a complete superposition between the two telluric directions, translating the fact that the variation of the resistivity is not $1 \mathrm{D}$, but rather $2 \mathrm{D}$ or $3 \mathrm{D}$. Major features of $2 \mathrm{D}$ resistivity model from the respective profiles were identified. These features include a set of lower resistive formations going from the surface to $1000 \mathrm{~m}$ depth, lying on a set of resistive formations that appears at the surface and below the lower resistive formations. However, a very conductive layer was observed in depth in the three profiles. These facts show that the study area is made up of mixture of both conductive and resistive materials, suggesting a prolongation of the overlap between the Congo Craton and the Pan-African in depth to the north and the location of the CC/Pan-African limit above $4^{\circ} \mathrm{N}$ parallel accordingly. Deeper electrical discontinuities, interpreted as faults following a NE-SW trend, were highlighted. All these new data suggest that the study area underwent an intense tectonic activity with ductile to brittle deformations due to the presence of the BOSZ.
\end{abstract}

\section{Introduction}

The Pan-African tectonic evolution in Cameroon is marked by large scale shear zones that have intensely transported early structures $[1,2]$. Cameroon neoproterozoic units belong to the North Equatorial Fold Belt (NEFB) which is affected by the Central African Shear Zone (CASZ) and defined as a pre-Mesozoic crustal strike-slip fault system $[1,2]$. The CASZ forms two branches in Cameroon: the Central Cameroon
Shear Zone (CCSZ) to the north and the Sanaga Fault (SF) to the south. The SF system is well represented in the east part of Cameroon by the Bétaré-Oya Shear Zone (BOSZ), where many mineralized substances are well established. The CCSZ is defined as a Pan-African postcollisional ductile fault, as a transcontinental structure marked by folds, parallel, or enechelon relays [3], and as major lineament of the Pan-African orogen of Central Africa [4]. 
In geophysical prospecting, AMT method is used and considered as a key tool in mineral exploration [5], in geothermal investigation [6-8], in potential radioactive waste disposal characterization [9], and in the identification of tectonics structures [10].

Magnetotelluric investigations have been carried out in the east region of Cameroon. A recent study [11] permitted through the use of the MT (AMT) high frequencies and $2 \mathrm{D}$ modelling of resistivity and phase pseudosections, to establish the tectonic setting and by the same way a system of folds and faults in southwestern part of the present study area. The interpretation of the AMT data and correlations with geological facts confirmed the author's proposition that the southwestern part of the study area is perfectly linked to the collision between the Pan-African Chain and the Congo Craton. Fractures have been highlighted from the image of the subsurface by combining the classical and the Bostick approaches in the interpretation of AMT data in the Akonolinga-Ayos region, westward from the current study area [12].

Other studies [13-15] by aeromagnetic and gravimetric methods were carried out in the southeastern part of the present study area and the results obtained were used to update the previous geological map and to highlight the presence of a deeper major tectonic feature, oriented E-W along the $4^{\circ}$ northern parallel emphasizing the presence of a E-W normal faults system in the Mengueme-Akonolinga region [13].

In spite of these studies, the fact that little or nothing is known about the internal structure of a large part of the eastern region of Cameroon still remains. Also, most of these studies are regional, therefore raising the debate about the internal structure and the continuity of the observed superficial structural lineaments at depth.

The aim of the present investigation was to study the electrical structure of the crust beneath the Garga Sarali neoproterozoic formations, which belong to the eastern gold district of Cameroon. This could help us understand better the relationship between the NE-SW, E-W, and N-S trending shear zone and the presence of mineralization at surface in that region of Cameroon. For that purpose, we have combined geophysical (AMT) investigations with some geological field data to enhance our results.

\section{Geology Setting}

2.1. Regional Geology. The study area belongs to the PanAfrican belt (Figure 1), also interpreted as the result of the convergence and collision between the steady Archaean Congo Craton to the south and one or two Paleoproterozoic plates $[16,17]$. Three major geological domains from south to north of the Pan-African belt in Cameroon are well identified [18-20].

(i) The southern domain, which comprises Pan-African meta-sedimentary units, contains formations that were thrust onto the Archaean Congo Craton towards the south, during an event marked by four stages of ductile deformations corresponding to E-W to
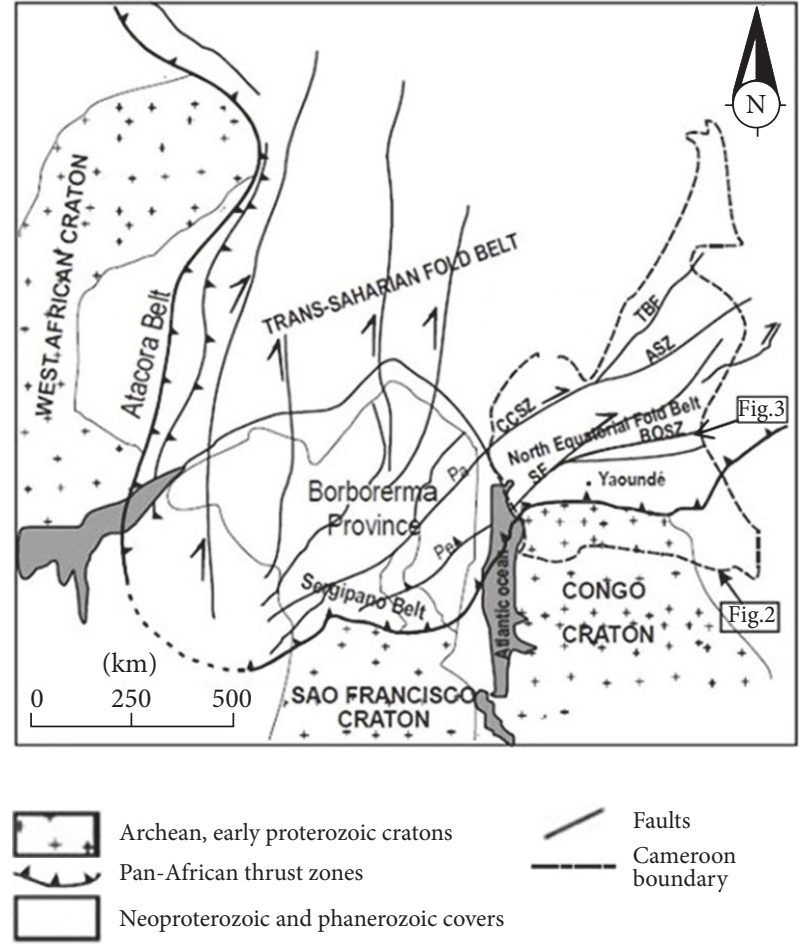

FIgURE 1: Predrift reconstruction of Pan-African and Brasiliano terranes (reproduced from Ganno et al., 2010, under the public domain; see location box in Figure 1): CCSZ: Central Cameroon Shear Zone; ASZ: Adamaoua Shear Zone; BOSZ: Bétaré-Oya Shear Zone; SF: Sanaga Fault; TBF: Tibati Banyo Fault; Pa: Patos Fault; Pe: Pernambuco Shear Zone.

NW-SE contraction (D1 and D3) and N-S to NE-SW extension (D2).

(ii) The central domain corresponds to a large NE-striking transcurrent fault zone, including the Adamaoua and Tibati Banyo faults to the north and the SF to the south.

(iii) The northern domain consists of subordinate $830 \mathrm{Ma}$ old metavolcanic rocks of tholeitic and alkaline affinities, which are associated with metasediments known as the Poli series and widespread 630-660 Ma old calc-alkaline plutonic rocks known as orthogneisses, which result from a major crustal accretion episode.

2.2. Local Geology. The study area (Figure 2) is located $30 \mathrm{~km}$ away from Bétaré-Oya, between latitudes $5^{\circ} 19^{\prime} \mathrm{N}$ and $5^{\circ} 31^{\prime} \mathrm{N}$ and longitudes $13^{\circ} 59^{\prime} \mathrm{E}$ and $14^{\circ} 10^{\prime} \mathrm{E}$. It belongs to the eastern part of the central domain and is characterized by a dentritic hydrographic network emphasizing a variety of tectonic features (Figure 3). Previous geological investigations recognized two contrasting terranes [21, 22]. The northwestern terrane consists mostly of NE-SW elongated low-grade schist with Au deposits, including a volcanoclastic schist (so-called Lom Schist), that is associated with subordinate conglomeratic quartzites and intruded by voluminous plutonites. The eastern terrane, by contrast, is characterized 


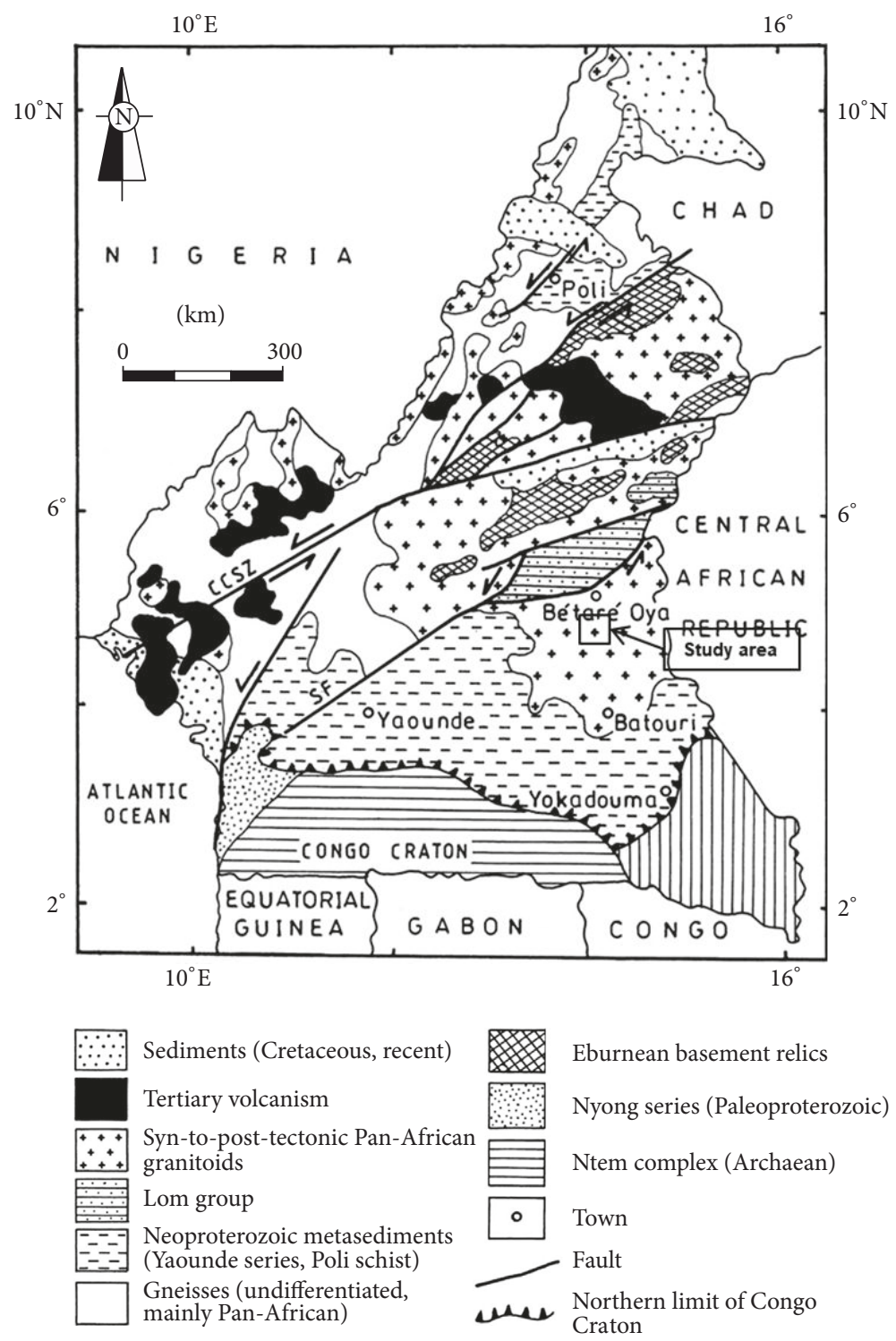

FIGURE 2: Regional structural setting of Cameroon (reproduced and modified from Suh et al., 2006, under the public domain).

by a lack of low-grade metasediments with $\mathrm{Au}$ deposits and by high-grade metamorphic gneiss and migmatites intruded by granite suites $[21,22]$. The boundary between these two terranes is marked by a several-meters-wide NE-trending mylonitic zone referred to hereafter as Bétaré-Oya Shear Zone (BOSZ).

Recent studies show that the area belongs to the central domain. The lithology is made up of lateritic duricrust terranes, migmatites and gneisses (ortho), schist referred to as the Lom Schist belt (Figure 3(c)), metaleucogranites, metagranodiorites, porphyritic granites (Figure 3(b)), fine grained granites, and some pegmatite veins [1].

The study area is affected by the strike-slip fault (Figure 1) known locally as the BOSZ and a relay of the SF which divided the study area into two parts: a northwestern and a southeastern region [1]. The southeastern zone is dominated by various gneissic granitoids and minor bodies of porphyritic granites, while the northwestern zone is dominated by late granitoids intrusions and early gneissic rocks with subordinate schist [1].

A preliminary assessment through a superposition of the structural map and the satellite images analysis of the area (Figure 4) displays an alignment of tectonic lines, lineaments, and foliations with the choice of the profiles, which are crosscutting the observed structural features.

\section{Method, Data Acquisition, and Processing}

3.1. Method. The magnetotelluric (MT) method finds its basic principles within the electromagnetic field theory [23], in which it is demonstrated that the MT wave is a plane wave [24]. The MT method is applied in structural geology and geothermal and mineral prospecting [12, 25-28]. In MT method, natural electromagnetic fields are used to investigate the electrical structure of the earth, based on its resistivity. The MT method is unique because of its capability to explore 


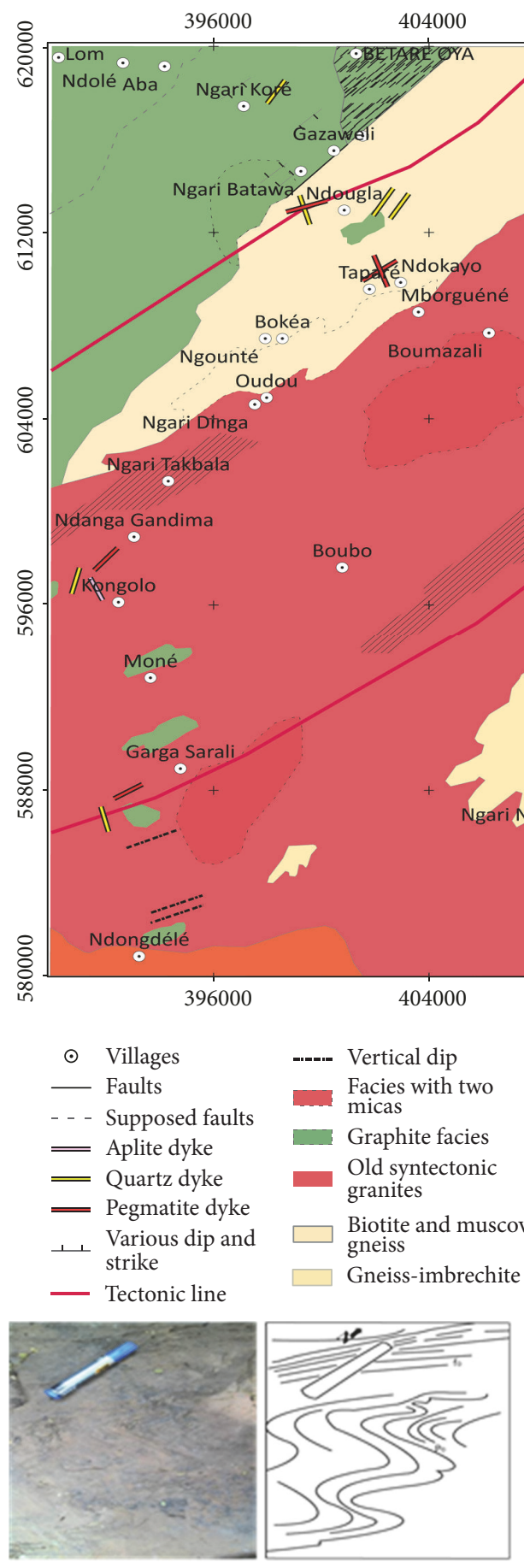

(a)

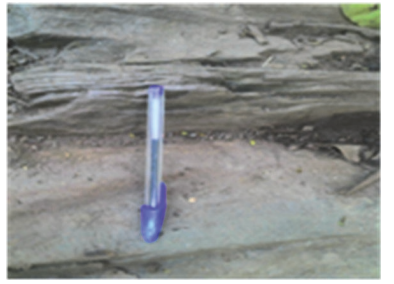

(c)
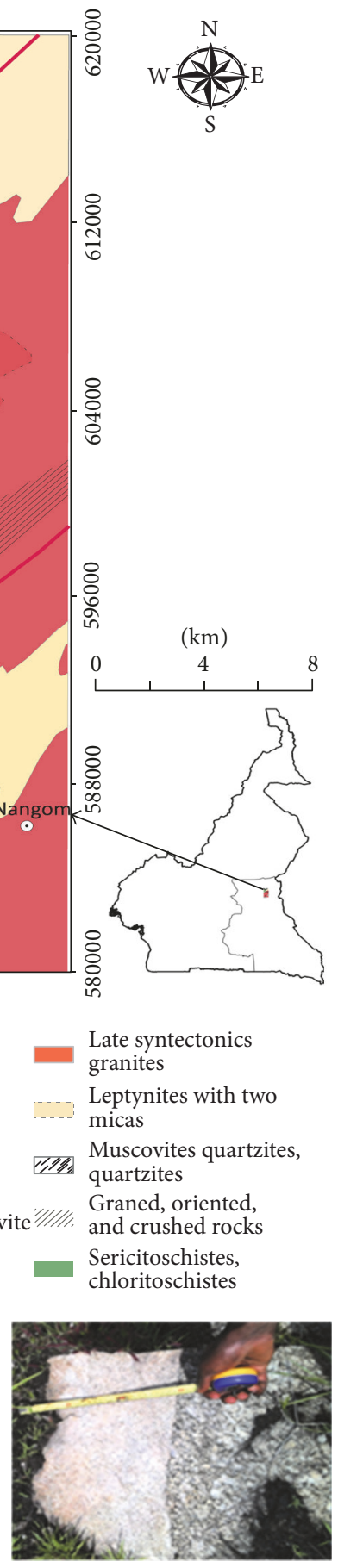

(b)

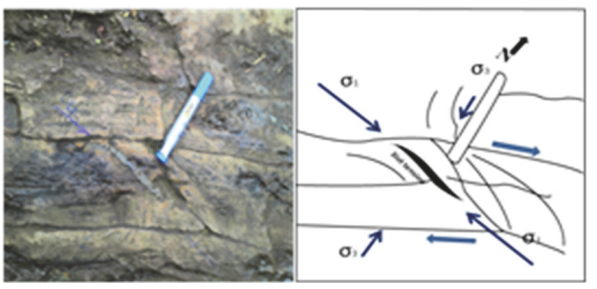

(d)

FIGURE 3: Geological map of the study area (reproduced and modified from Gazel et al., 1954, under the public domain) with AMT soundings points; field observation showing folds on a schist (a); porphyritic granite (b); schistosity (c); joint tension/dextral shear in granite (d). 


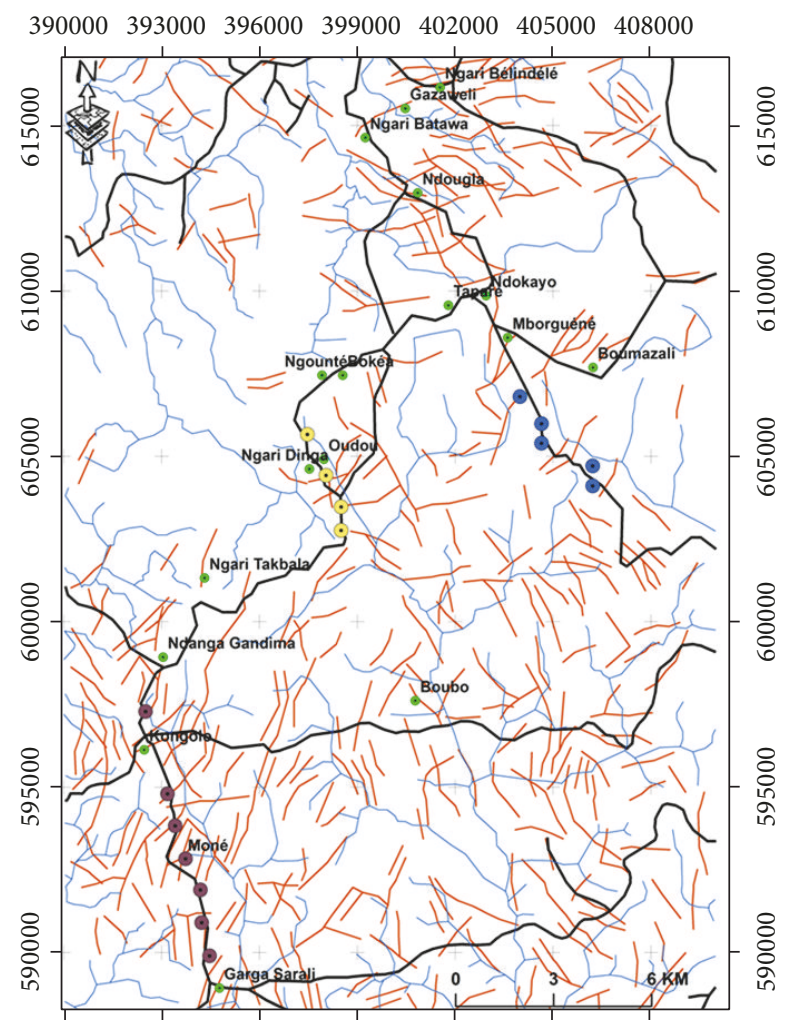

390000393000396000399000402000405000408000

$$
\begin{array}{ll}
\text { - Oudaï AMT stations } & \text { River } \\
\text { - Garga Sarali AMT stations } & \text { - Road } \\
\text { - Ndokayo AMT stations } & - \text { Lineaments } \\
\text { - Locality } &
\end{array}
$$

FIGURE 4: Foliation (minor lineaments) of the study area (reproduced and modified from Noutchogwe et al., 2011, under the public domain).

from very shallow to very great depth without using any artificial power source and with no environmental impact. MT data acquisition involves the simultaneous measurement of natural electric and magnetic fields at any point on the earth's surface, in order to deduce the resistivity of rocks directly under the receiver. In reality, the subsurface is inhomogeneous, and the apparent resistivity is determined instead of the true resistivity $[10,29,30]$, according to the following relation: $\rho_{a}=0.2 T\left(E_{x} / E_{y}\right)^{2}$, where $T$ is the period of the wave in seconds, $E_{x}$ is the electrical field in the $O X$ direction, and $H_{y}$ the magnetic field in the $O Y$ direction perpendicular to $O X$.

The MT investigation at high frequencies is known as the audio frequency MT or simply audiomagnetotellurics (AMT). AMT enables investigations from shallower depths $(1 \mathrm{~m})$ to more than 1 kilometre (depths of 7 to $10 \mathrm{~km}$ are reachable in some cases). Natural electromagnetic sources related to the MT/AMT method originate from spherics and thunderstorms that hit the earth and consequently induce a ground electromagnetic field. However, when dealing with AMT soundings, natural signals are generally weak in the $2000-5000 \mathrm{~Hz}$ frequency range, also known as the AMT dead-band $[24,31]$. This weakness in natural signals strength is improved by using artificial signals which strengthen the background fields. The technique is a variant of the AMT called controlled source AMT (CSAMT).

AMT interpretation software is used to estimate the ground electrical impedance from a series of simultaneous measurements of local electric $(E)$ and magnetic $(H)$ field fluctuations made over a period of several minutes. The ground impedance is a complex function of frequency where higher-frequency data are influenced by shallow or nearby features while lower-frequency data are influenced by deep structures [32]. An AMT sounding provides an estimate of vertical resistivity distribution and indicates the geoelectrical complexity beneath a sounding site.

The resistivity of geologic unit depends largely on its fluid content, porosity, degree of fracturing, temperature, and conductive mineral content [33]. Saline fluids within the pore spaces and fracture openings can reduce resistivity in a rock matrix. Also, resistivity can be lowered by the presence of conductive clay minerals, carbon, and metallic mineralization. Increased temperature causes higher ionic mobility and mineral activation energy thereby reducing rock resistivity significantly. Unaltered and unfractured igneous rocks are normally very resistive, with values typically $1,000 \mathrm{ohm}-\mathrm{m}$ or greater [34]. Also, fault zones can appear as low resistivity units of less than $100 \mathrm{ohm}-\mathrm{m}$ when they are comprised of rocks fractured enough to have hosted fluid transport and consequently mineralogical alteration [34].

3.2. Data Acquisition. To conduct the study, geophysical data were collected with a Stratagem EH-4 system from [32]. Stratagem EH-4 is a system which utilizes both natural and man-made electromagnetic signals to obtain continuous electrical sounding over the earth surface. The Stratagem system consists of two basic components (Figure 5): (1) a receiver unit that allows the use of four/five electrodes and two magnetic sensors and (2) a transmitter which provided artificial signals required to augment the natural field and improve the data quality $[24,32]$.

AMT data were acquired using the Geometrics STRATAGEM EH4 unit along three profiles following Garga Sarali, Ndokayo road (Figure 1), with a total of 16 soundings. These data were processed to provide tensor impedance measurements for interpreting complex 2D structures. To acquire soundings, the STRATAGEM EH4 was assembled at each station with a 25-meter dipole length in the $X$ (TE mode) and $Y$ (TM mode) directions using 4 buffered electrodes with stainless steel stakes. The choice of the orientation of profiles and the soundings points has been made on the basis of geological data of the area. In fact, the main structural trend of the area followed the N042. Data acquisition was performed far away from electrical networks and human activities to avoid noises. Ndokayo profile is $4090 \mathrm{~m}$ in length, while Oudou is $3200 \mathrm{~m}$ in length and Garga Sarali is $7700 \mathrm{~m}$ in length. According to the geological map [21] and field observations, the three profiles are crossing two mica porphyritic granites, porphyritic granite, embrechites gneisses, and schists. Distances between profiles and the base profile Ndokayo are reported in Table 1. 


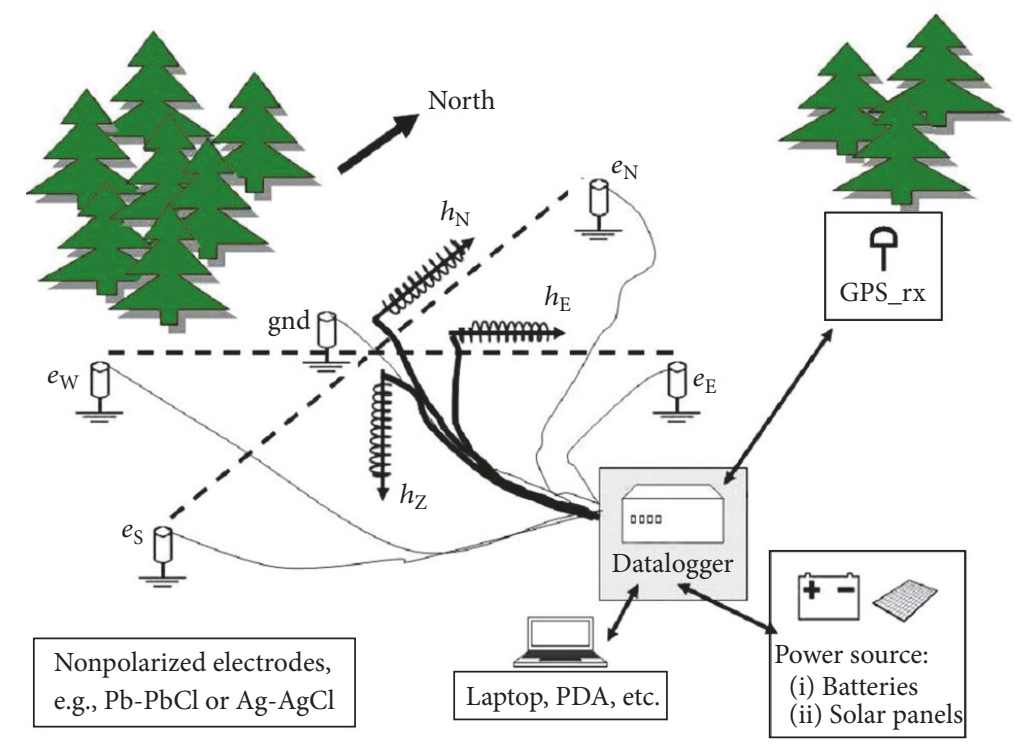

FIGURE 5: Schematic diagram of an AMT measurement site (reproduced from Lahti, 2015, under the public domain).

TABLE 1: Distances between profiles and the base profile Ndokayo.

\begin{tabular}{|c|c|c|c|c|}
\hline $\mathrm{N}^{\circ}$ & $\begin{array}{l}\text { AMT profile } \\
\text { name }\end{array}$ & Number of stations & Stations spacing $(\mathrm{m})$ & $\begin{array}{l}\text { Distance } \\
(\mathrm{km})\end{array}$ \\
\hline (1) & Ndokayo & 05 (Nd1, Nd2, Nd3, Nd4) & $\begin{array}{l}\mathrm{Nd} 1 \text { to } \mathrm{Nd} 2=1040 \mathrm{~m} ; \mathrm{Nd} 2 \text { to } \mathrm{Nd} 3=1010 \mathrm{~m} ; \\
\mathrm{Nd} 3 \text { to } \mathrm{Nd} 4=1010 \mathrm{~m} ; \mathrm{Nd} 4 \text { to } \mathrm{Nd} 5=1030 \mathrm{~m}\end{array}$ & 0 \\
\hline (2) & Oudou & 04 (Oud1, Oud2, Oud3, Oud4) & $\begin{array}{l}\text { Oud1 to Oud } 2=703 \mathrm{~m} ; \text { Oud } 2 \text { to Oud } 3= \\
1067 \mathrm{~m} ; \text { Oud } 3 \text { to Oud } 4=1370 \mathrm{~m}\end{array}$ & 7 \\
\hline (3) & Garga Sarali & $\begin{array}{c}07 \text { (GS1, GS2, GS3, GS4, GS5, } \\
\text { GS6, GS7) }\end{array}$ & $\begin{aligned} & \mathrm{GS} 1 \text { to } \mathrm{GS} 2=1040 \mathrm{~m} ; \mathrm{GS} 2 \text { to } \mathrm{GS} 3=990 \mathrm{~m} ; \\
& \mathrm{GS} 3 \text { to } \mathrm{GS} 4=1020 \mathrm{~m} ; \mathrm{GS} 4 \text { to } \mathrm{GS} 5=1050 \mathrm{~m} ; \\
& \text { GS6 to } \mathrm{GS} 7=2600 \mathrm{~m}\end{aligned}$ & 9 \\
\hline
\end{tabular}

3.3. Data Processing. After transforming the recorded timeseries data to frequency domain, standard processing method was employed to determine the apparent resistivity and phase tensor at each sounding site [32]. The apparent resistivity and phase are related through the Hilbert transform. The phase is proportional to the slope of the apparent resistivity curve on a log-log plot, except from the baseline of 45 degrees [27]. Predicted values of the electric field can be computed from the measured values of the magnetic field [27]. The coherence of the predicted electric field with the measured electric field is a measure of the signal-to-noise ratio provided in the E-predicted coherency plots. The coherency obtained during the data collection has a signature that is acceptable with a value that is aligned almost to a good precision (Figure 6).

The electric and magnetic fields were measured in two directions (orthogonal and horizontal). The tensor impedance, parameterised as apparent resistivity and phase, was obtained from the time-series signals. Signals were converted to complex cross-spectra using a Fourier-transform technique. A least-squares, cross-spectral analysis was then used to solve for a transfer function (impedance) that relates the observed electric fields to the magnetic fields under the assumption that the earth consists, respectively, of two inputs

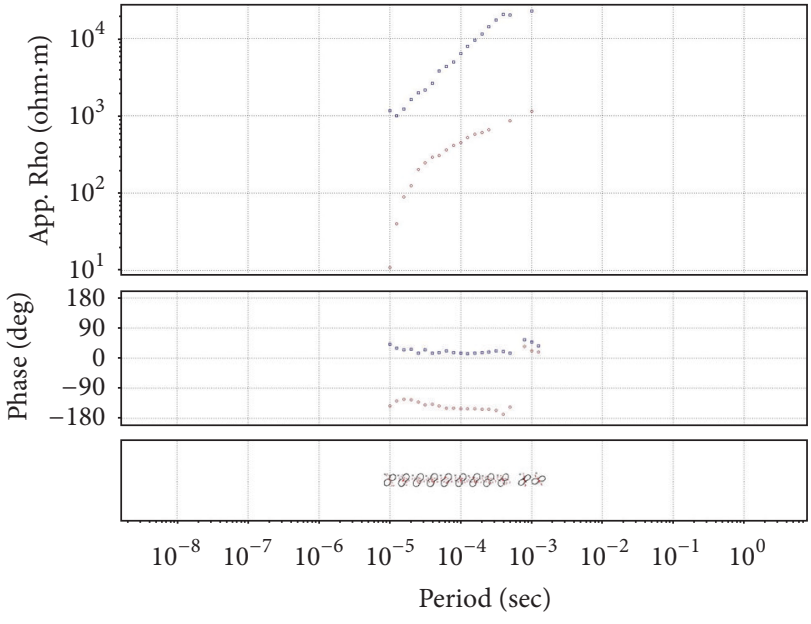

FIgURE 6: Dimensionality tests (apparent resistivity and phase) of station Oud4 of the Oudou profile [TE mode; TM mode].

(magnetic fields) and two outputs (electric fields) linear system [32].

For two-dimensional (2D) earth model, the diagonal terms of the impedance tensor are zero. The off-diagonal 
terms were decoupled into transverse electric (TE) and transverse magnetic (TM) modes. When the geology satisfies the $2 \mathrm{D}$ assumption, the TE mode measures electric field parallel to geologic strike and the TM mode measures electric field perpendicular to geologic strike. Data were processed with a fixed rotation parallel and perpendicular to regional strike. The Stratagem Resistivity Plotter (program made to visualize and edit $2 \mathrm{D}$ modelling results produced by the Imagem software [32]) was used for making 2D plots of Stratagem Resistivity data. This program uses the Python Matplotlib scientific plotting. The program allows the combination of high and low frequency mode soundings into one plot.

Analysis of the curves of dimensionality tests (Figure 6) shows that there is not always a complete superposition between the two telluric directions. This confirms the fact that the variation of the resistivity is not $1 \mathrm{D}$, but rather $2 \mathrm{D}$ or 3D. Nevertheless, the superposition observed can refer to a model of structure, $1 \mathrm{D}$ or $2 \mathrm{D}$, but in comparison with complex tectonics of the study area, $2 \mathrm{D}$ interpretation is more indicated.

Values of the electric field can be estimated from measurements of the magnetic field [27]. Coherence between the values of the electric field predicted and those measured is the ratio between the signal and the noise ([signal]/[noise]). This ratio defines the quality of the recorded data. The values of coherence lie between 0 and 1 (where 0.5 corresponds to a level of signal equal to the noise). Figure 7 shows the coherency test on station 2 of the Ndokayo profile and that of station 2 of the Oudou profile. For this study, only the data with a coherency below or equal to 0.7 have been considered (Figure 7).

\section{Results}

\subsection{Resistivity Profiling Curves}

4.1.1. Ndokayo Profile. The Ndokayo resistivity profile (Figures $8(\mathrm{a})$ and $8(\mathrm{~b})$ ) presents a zigzag form testifying the variation of the resistivity with depth, with peaks that characterize the changes in the nature of the bodies or formations crossed by the current. Observation of the Ndokayo profile makes it possible to locate two (02) zones of anomalies. Indeed, the variation of the resistivity between the $\mathrm{Nd} 1$ and $\mathrm{Nd} 3$ stations in the high frequency domain shows the passage of the current in the fairly resistive zones. This evolution is abruptly interrupted in the field of low frequencies marked by a sharp drop of the resistivity. This reflects the existence in depth of a sufficiently conductive body. This phenomenon is still observed between the $\mathrm{Nd} 4$ and $\mathrm{Nd} 5$ stations, where a discontinuity is identified at the $\mathrm{Nd} 4$ station (line in red).

4.1.2. Garga Sarali Profile. At both low and high frequencies domain, the resistivity profiles from the Garga Sarali (Figures $7(\mathrm{c})$ and $7(\mathrm{~d})$ ) display low resistivity values at great depth. Particularly, there is a very conductive channel between stations GS2 and GS6. The above-stated channel seems to be bordered by two major electrical discontinuities at GS2 and GS6 (Figures 8(c) and 8(d)). These discontinuities can be interpreted as faults. The irregular variation of the resistivity confirms the heterogeneity of the basement of the area and suggests its folded character and its geological setting marked by brittle-ductile deformations.

4.1.3. Oudou Profile. The curves obtained from the Oudou profile (Figures 9(a) and 9(b)) disclose a main electrical discontinuity at high and low frequencies domain, centred at station Oud2 and characterized by a decrease of the resistivity. Geologically, this rough variation of the resistivity highlights the transition of a facies of high resistivity to facies of low resistivity. This passage would thus correspond to an electric discontinuity. The resistivity variation also suggests the heterogeneity of the environment.

\subsection{Pseudosections}

4.2.1. Ndokayo Profile. The observation of the apparent resistivity and phase pseudosection of the Ndokayo profile helps to identify (Figure 10) a conductive area that extends from station $\mathrm{Nd} 1$ to station $\mathrm{Nd} 4$ and beyond at high frequencies, which was more emphasized between stations $\mathrm{Nd} 2$ and $\mathrm{Nd} 4$. Also, a highly conductive zone was observed at depth (low frequency domain), particularly below the stations $\mathrm{Nd} 3, \mathrm{Nd} 4$, and Nd5. A precise observation shows that this area is separated from the first conductive zone (high frequency domain) by a resistive zone whose signatures are visible at the surface at the station Nd5. This resistive zone extends in depth with an emphasis under stations $\mathrm{Nd} 1$ and $\mathrm{Nd} 3$, where it seems to represent the basement materials. However, there is a conductive channel that divides this resistive zone in two entities. The observed facts suggest the presence of a discontinuity in depth.

4.2.2. Garga Sarali Profile. The observation of apparent resistivity and phase pseudosections (Figure 11) of the Garga Sarali profile shows a conductive zone between GS1 and GS2 and surrounding GS5 and GS6 which is observed as high frequency domain along the profile. The second that has underlain the first one is more resistive, and it is undulated with depressions at stations GS2 and GS6, suggesting the presence of electric discontinuities.

A third zone appearing beneath the second is conductive as the first zone. However, some resistive layers below the station GS7 are identified at low frequencies. These features (Figure 11) show that the area testified an intense tectonic event that is underlined by a deeper electric discontinuity under station GS5.

4.2.3. Oudou Profile. The apparent resistivity and phase pseudosections of the Oudou profile (Figure 12) underline a depressions process which affects the resistive formation cropping out at station Oud4 and extends to a great depth (low frequency domain).

This depression is marked by conductive material fillings that extend from station Oudl across the section, over 3000 meters. This conductive region extends in depth (medium frequency) below the station Oud2, where it seems to separate 


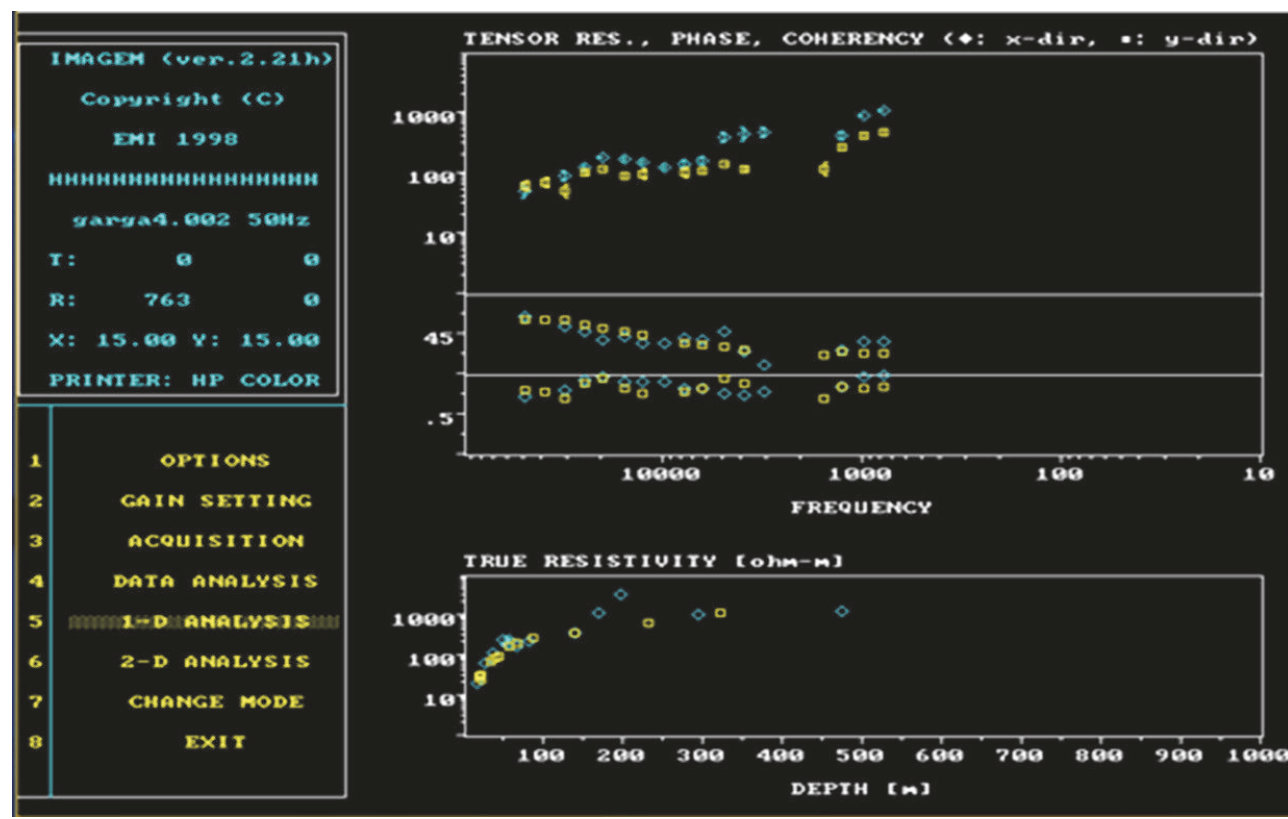

(a)

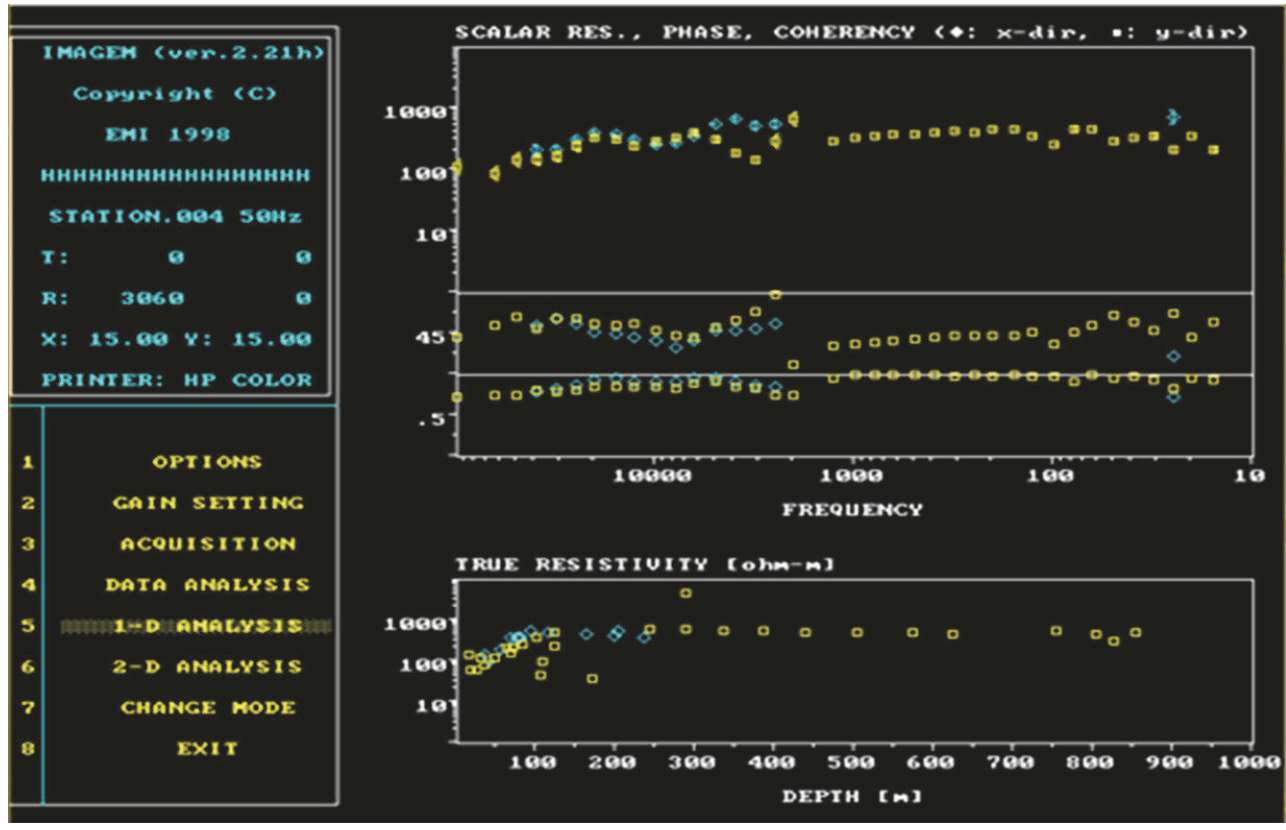

(b)

Figure 7: Coherency test from station 2 of the Ndokayo profile (a) and from station 2 of the Oudou profile.

into two high resistivity blocks and appear again at great depth (low frequency domain) below stations Oud3 and Oud4. This disposition suggests the presence of a discontinuity at the station Oud 2 and a folding process that has affected the area.

\subsection{Geoelectrical Section (2D Modelling Pseudosection)}

4.3.1. Ndokayo Profile. Figure 13 represents the geoelectrical section of Ndokayo profile. It generally shows the inhomogeneous character of the area.
The major features observed on the $2 \mathrm{D}$ geoelectrical section from the Ndokayo profile are given as follows (from surface to depth):

(i) The first geoelectrical layer (Rho $\leq 1000 \Omega \cdot \mathrm{m})$ spans from $\mathrm{Nd} 1$ to beyond $\mathrm{Nd} 4$, where it is interrupted by the outcrop of the underlying layer (thus suggesting a horizontal discontinuity). This first layer reaches $400 \mathrm{~m}$ depth below $\mathrm{Ndl}$ and $300 \mathrm{~m}$ below $\mathrm{Nd} 4$. However, it slightly thins between $\mathrm{Nd} 2$ and $\mathrm{Nd} 4$. The observed conductive zone may correspond to 


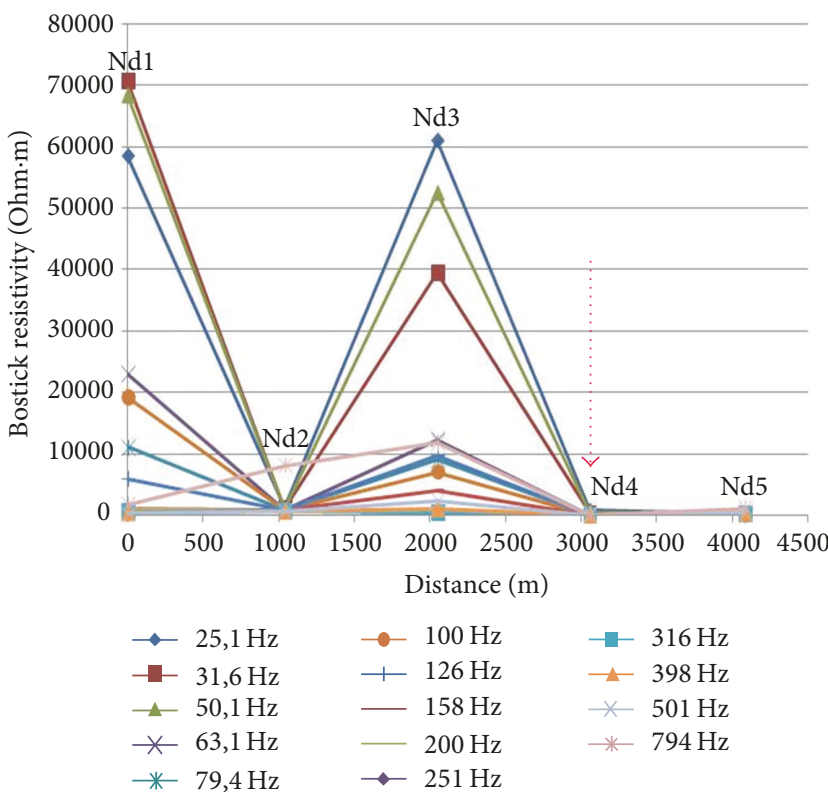

(a)

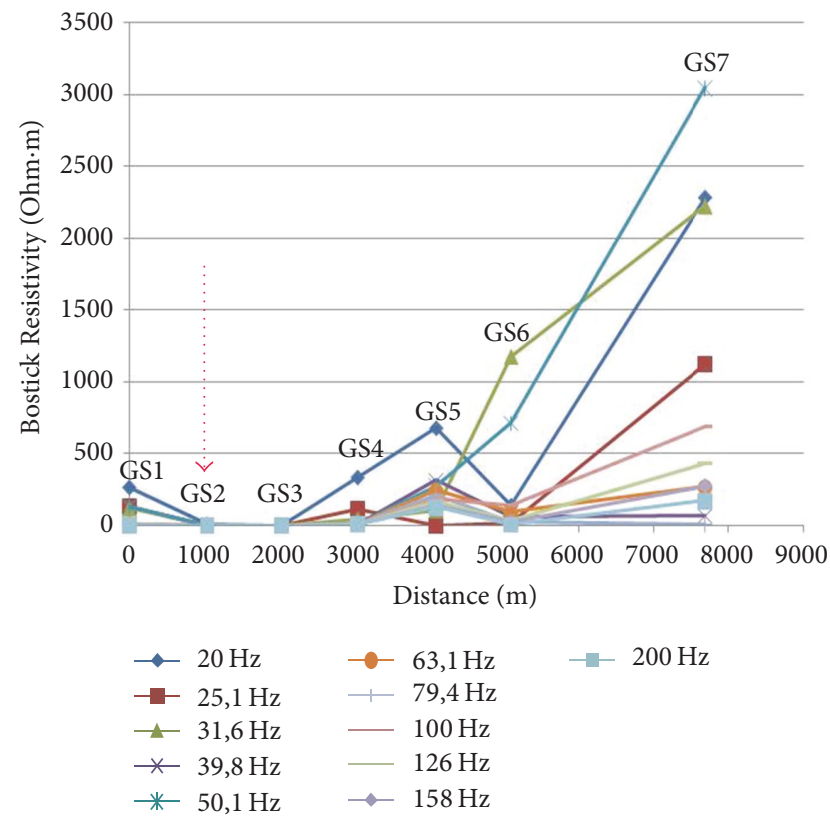

(c)

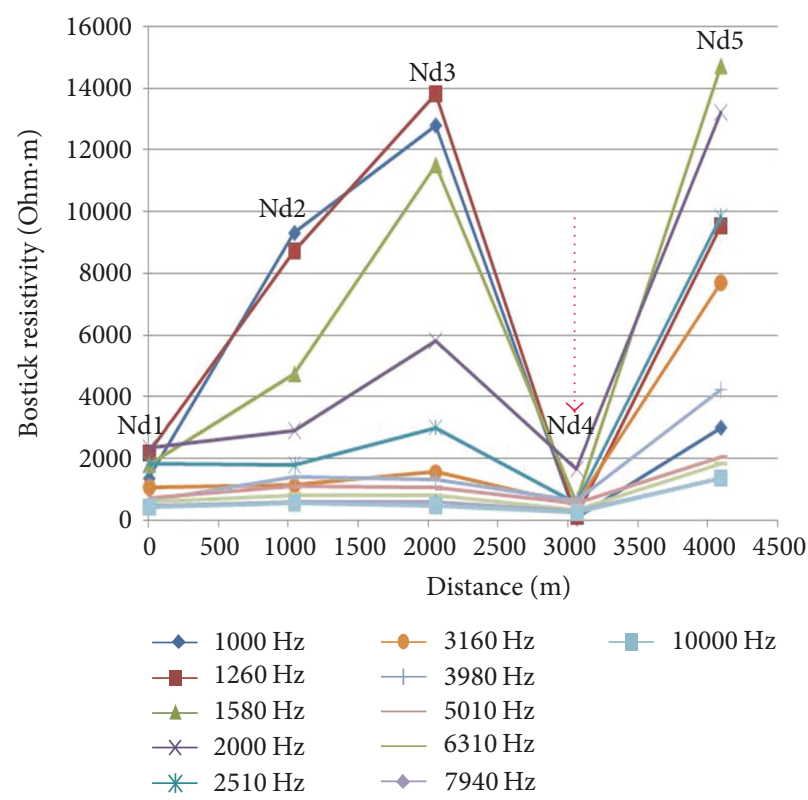

(b)

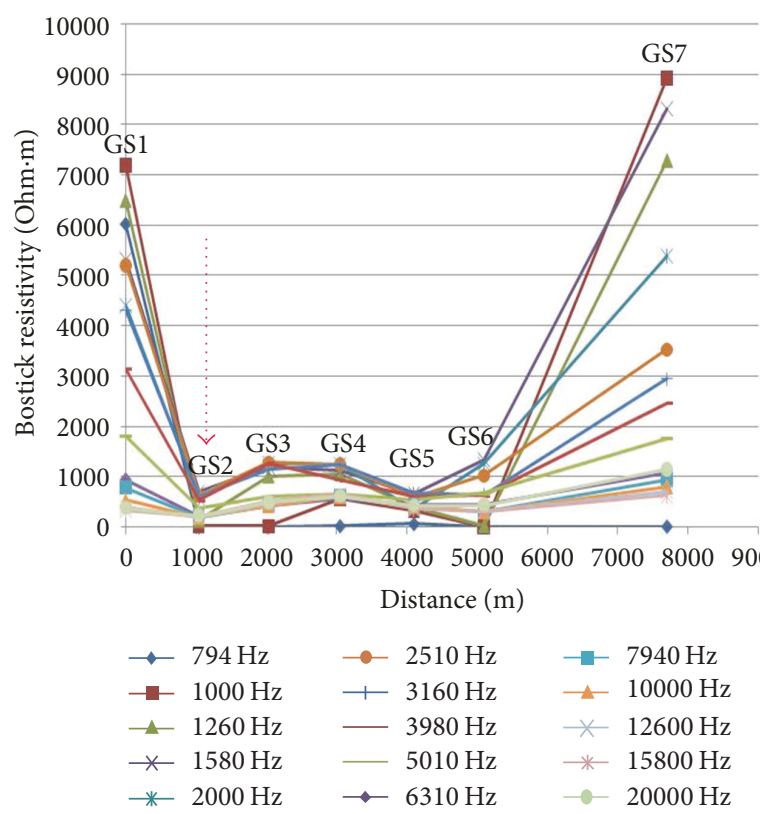

(d)

FIGURE 8: Resistivity profiling curves for Ndokayo profile, respectively, at low frequencies [25.1 Hz-501 Hz] (a) and at high frequencies [794 Hz-10000 Hz] (b); resistivity profiling curves for Garga Sarali profile, respectively, at low frequencies $[20 \mathrm{~Hz}-200 \mathrm{~Hz}](\mathrm{c})$ and at high frequencies $[794 \mathrm{~Hz}-20000 \mathrm{~Hz}](\mathrm{d})$.

sediment and metasediment deposit from the Lom series.

(ii) The second geoelectrical layer $(1000 \Omega \cdot \mathrm{m}<\mathrm{Rho} \leq$ $4000 \Omega \cdot \mathrm{m})$ appears in depth between $400 \mathrm{~m}$ and $600 \mathrm{~m}$ at $\mathrm{Ndl}$, between $300 \mathrm{~m}$ and about $1100 \mathrm{~m}$ at $\mathrm{Nd} 4$, and from surface to $600 \mathrm{~m}$ depth at $\mathrm{Nd} 5$. It is characterized by a paroxysmal bulge at $\mathrm{Nd} 3$. This layer outcrops beyond $\mathrm{Nd} 4$ (from the profile's origin) where it suggests a horizontal discontinuity therein, which could be interpreted as a change in the nature of encountered formation. Also, the trace on the section depicts an oval shaped target below station Nd4. The layer's attitude around station $\mathrm{Nd} 4$ infers a collapse of the underlying terrains. The second geoelectrical layer can be interpreted as two mica porphyritic granites, according to the resistivity range values.

(iii) The third geoelectrical layer $(4000 \Omega \cdot \mathrm{m}<\mathrm{Rho}<$ $7000 \Omega \cdot \mathrm{m}$ and above $7000 \Omega \cdot \mathrm{m})$ appears between 


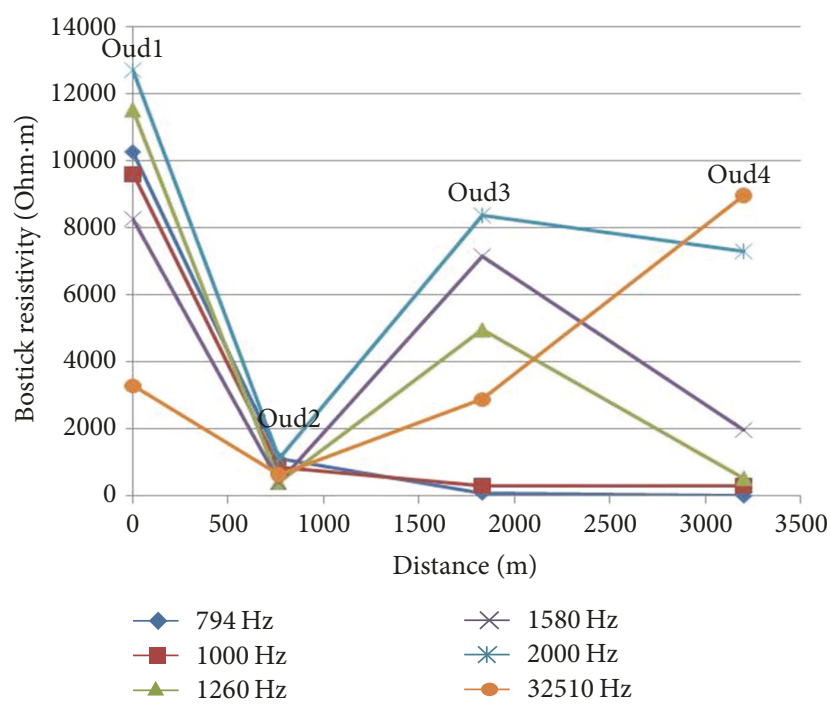

(a)

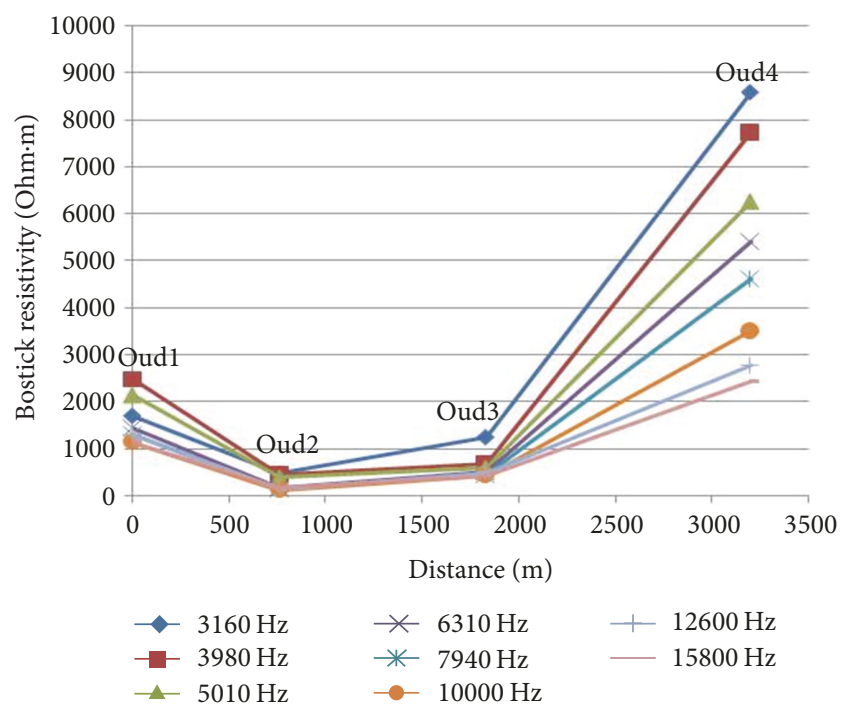

(b)

FIGURE 9: Resistivity profiling curves for Oudou profile at low frequencies [ $794 \mathrm{~Hz}-2000 \mathrm{~Hz}$ (a); resistivity profiling curves for Oudou profile at high frequencies $[2510 \mathrm{~Hz}-15800 \mathrm{~Hz}](\mathrm{b})$.

$600 \mathrm{~m}$ and up to $1000 \mathrm{~m}$ depth at Nd1 where it is embedded within the second layer. It has an average thickness of $200 \mathrm{~m}$ along the whole profile. These uplifts are separated by a depression that is bounded by steep slopes, inside of which two strongly resistive blocks are identified, respectively (Rho $\geq 7000 \Omega \cdot \mathrm{m}$ ). It presents alternating upraised (from $\mathrm{Nd} 2$ to $\mathrm{Nd} 3$ and at $\mathrm{Nd5}$ ) and downthrown (centred at $\mathrm{Nd} 4$ ) blocks. The upraised block from $\mathrm{Nd} 2$ to $\mathrm{Nd} 3$ is responsible for the thinning of the overlying formations therein. Besides, the downthrown block is probably a collapse of the basement between $\mathrm{Nd} 3$ and $\mathrm{Nd} 5$. The third geoelectrical layer can be interpreted as formations that constitute the basement (probably granitoids).

A main electrical discontinuity is identified on the geoelectrical section of Ndokayo profile. This highlighted discontinuity can be interpreted as vertical faults with a NESW strike based on their shape and orientation. The fault may have probably resulted from the fracturing and the compartment of the basement along with vertical displacement of blocks (Figure 13).

4.3.2. Oudou Profile. The observation and analysis of the geoelectrical section of the Oudou profile (Figure 14) enable outlining features or layers having the same geoelectrical characteristics as those from the first profile (Figure 14). The features as observed from shallow depth (Figure 14) are given as follows:

(i) The first geoelectric layer corresponds to conductive terrains (Rho $\leq 1000 \Omega \cdot \mathrm{m})$. It has an average thickness of $100 \mathrm{~m}$ with a perceptible thinning beyond station Oud3.

(ii) The second layer $(1000 \Omega \cdot \mathrm{m}<$ Rho $\leq 4000 \Omega \cdot \mathrm{m})$ appears between $100 \mathrm{~m}$ and $400 \mathrm{~m}$ beneath Oud1, thickens up to $600 \mathrm{~m}$ at Oud2, and then becomes thinner up to the end of the profile.

(iii) The third layer $(4000 \Omega \cdot \mathrm{m}<$ Rho $<7000 \Omega \cdot \mathrm{m})$ corresponds to more resistive terrains. This layer has an average thickness of $300 \mathrm{~m}$. It is marked by a steep slope from Oud1 to Oud2 and gentle slope from Oud3 to Oud4. These two slopes configure the third layer like a boat which dips to the SE (beginning of the profile). The boat-like shape of the third layer matches that of the underlying fourth layer (Rho $\geq 7000 \Omega \cdot \mathrm{m})$ which is interpreted as the basement in the Oudou area.

4.3.3. Garga Sarali Profile. In the same way as in the previous profiles, the $2 \mathrm{D}$ geoelectrical section from the profile (Figure 15) in the Garga Sarali area exhibits a four-layer earth model. Downward from surface, the feature appears as follows:

(i) The first layer (Rho $\leq 1000 \Omega \cdot \mathrm{m}$ ) surmounted by a very low resistive layer has an average thickness of $200 \mathrm{~m}$. It is characterized by undulations induced by the roughness of the underlying layer's topography.

(ii) The second layer $(1000 \Omega \cdot \mathrm{m}<\mathrm{Rho} \leq 4000 \Omega \cdot \mathrm{m})$, as stated above, has a very irregular topography affecting the thickness. However, between stations GS3 and GS6, that thickness increases up to a mean value of $600 \mathrm{~m}$. A nucleus of conductive materials is observed, especially at GS4. The isoresistivity contours are subvertical at GS3 and GS6, suggesting the presence of discontinuities at these points, respectively.

(iii) The third horizon is characterized by resistivity values between $4000 \Omega \cdot \mathrm{m}$ and $7000 \Omega \cdot \mathrm{m}$. with a strong bending from GS1 to GS3 and subvertical contours 


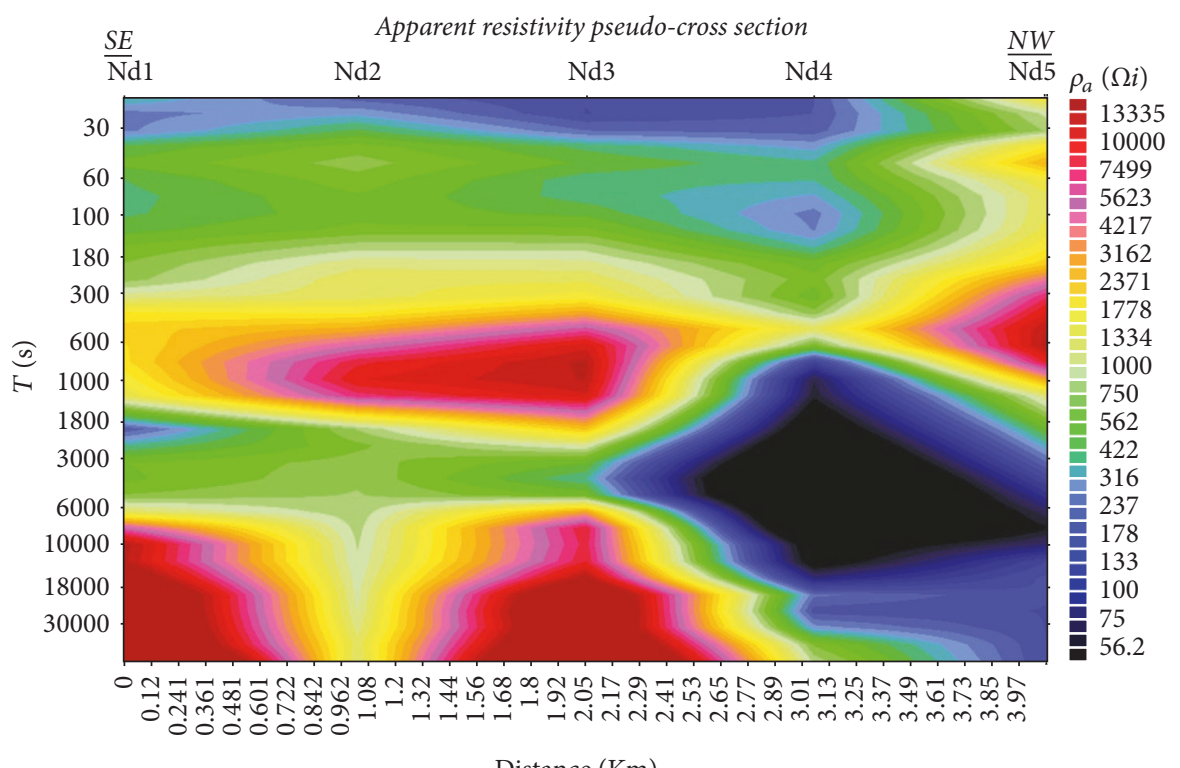

Distance $(\mathrm{Km})$

(a)

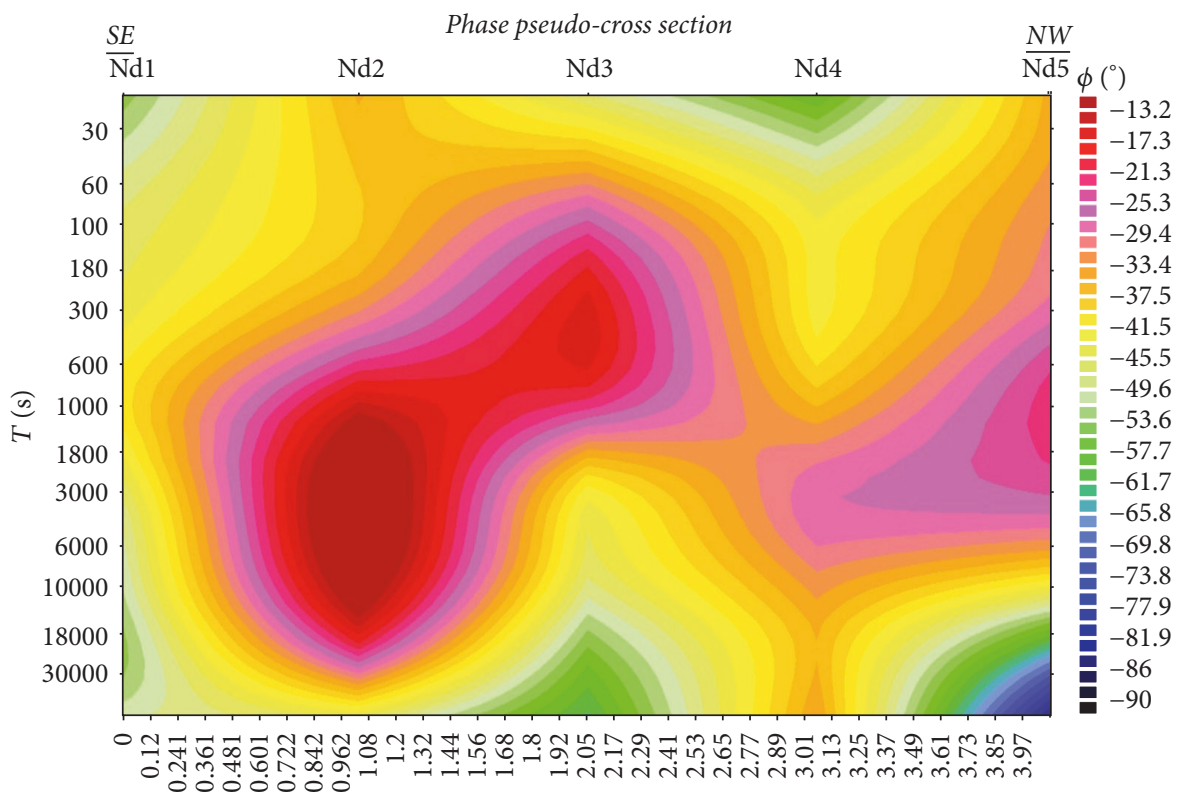

Distance $(\mathrm{Km})$

(b)

FIGURE 10: Apparent resistivity (a) and phase (b) pseudo-cross section of Ndokayo profile.

at GS3 and GS6. These subvertical contours confirm the presence therein of the discontinuities highlighted in the layer above (the second layer). These discontinuities delineate a graben between GS3 and GS6, probably induced by the collapse of the basement in the Garga Sarali area.

The geoelectrical section obtained along Garga Sarali profile shows folded structures and two vertical electrical discontinuities at GS4 and GS6 interpreted as faults oriented NE-SW. These faults seem to be associated with the tectonic events.
The results obtained from all the profiles above point to the fact that the study area has undergone deformation by folding and faulting processes. The identified electrical discontinuities followed NE-SW direction and are correlated with the CCSZ. Furthermore, the study area is made up of a mixture of both resistive and conductive formations. Recent studies $[10,12]$ suggest that the resistive formations account for the Congo Craton (CC) and the conductive ones belong to the Pan-African system; this mixture of materials suggests a prolongation of the overlap between the CC and the Pan-African to the north at great depth. Hence, the study suggests that the CC/Pan-African 


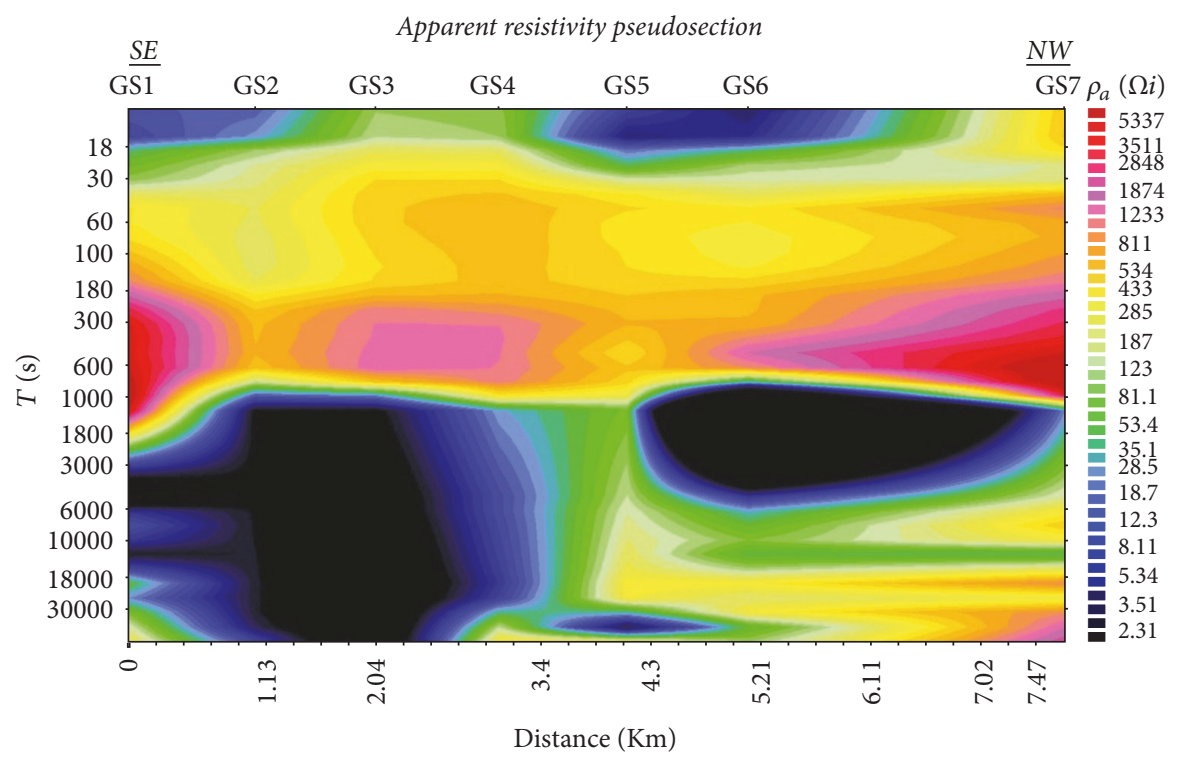

(a)

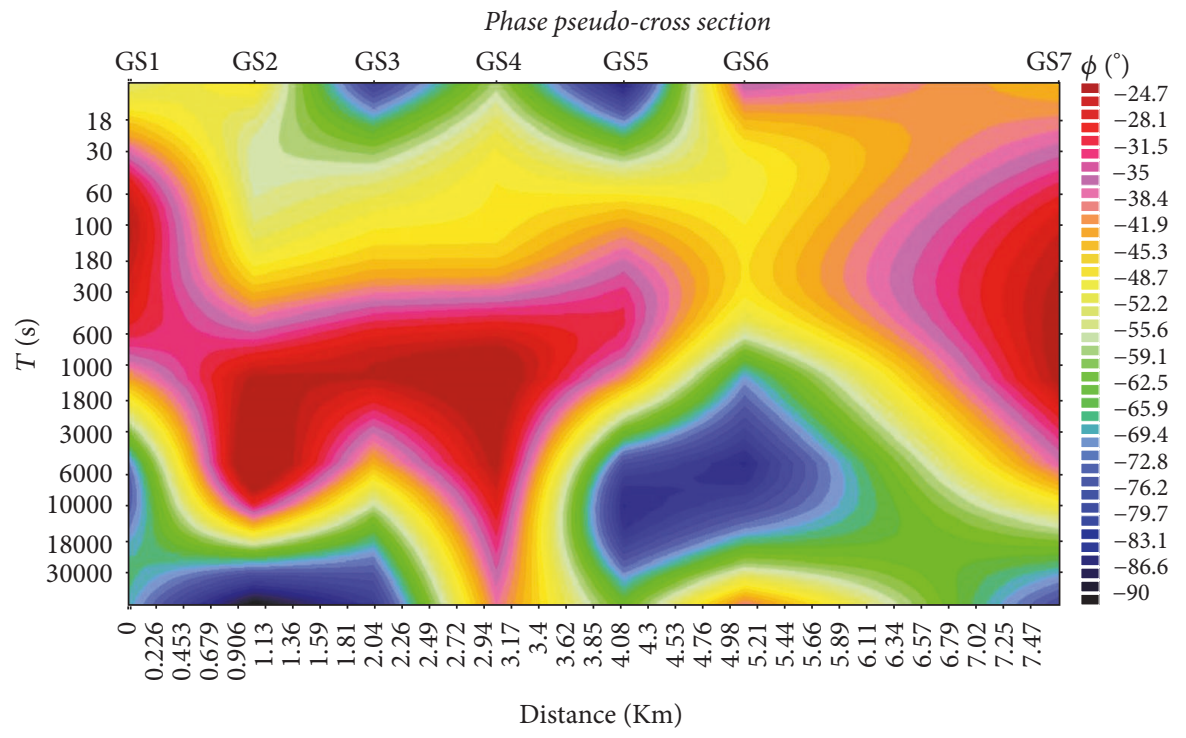

(b)

FIGURE 11: Apparent resistivity (a) and phase (b) pseudosection of Garga Sarali profile.

limit is located beyond latitude $4^{\circ} \mathrm{N}$. We can therefore assume that the study area underwent a multiphase tectonic activity.

\section{Discussion}

Field observations, existing geological data, and satellite imagery analysis of the study area, combined with AMT investigation, show that the subsurface resistivity distribution along the three profiles is in similar geological and structural environments. Ndokayo profile is crossing mica porphyritic granites, while Oudou profile runs over porphyritic and embrechite gneisses and Garga Sarali profile was on the Lom schists and porphyritic granites.
The analysis of satellite imagery and the relevant surface structural lineaments confirms the presence of three structural families with a main NE-SW orientation followed by NNE-SSW to N-S and E-W (Figure 3). Some electrical discontinuities interpreted as faults and oriented NE-SW as the BOSZ were highlighted. A major fault was identified down the station $\mathrm{Nd} 4$ of the Ndokayo profile, while two (02) other faults were identified along the Garga Sarali profile (GS4 and GS6). The irregular shape of isoresistivity contours (folds, vertical to subvertical) and the geological facts (crushed and oriented rocks) allow us to believe that an intense tectonic activity has taken place in the study area. They have the same orientation as the surface structural lineaments and some are correlating (Figure 16). 


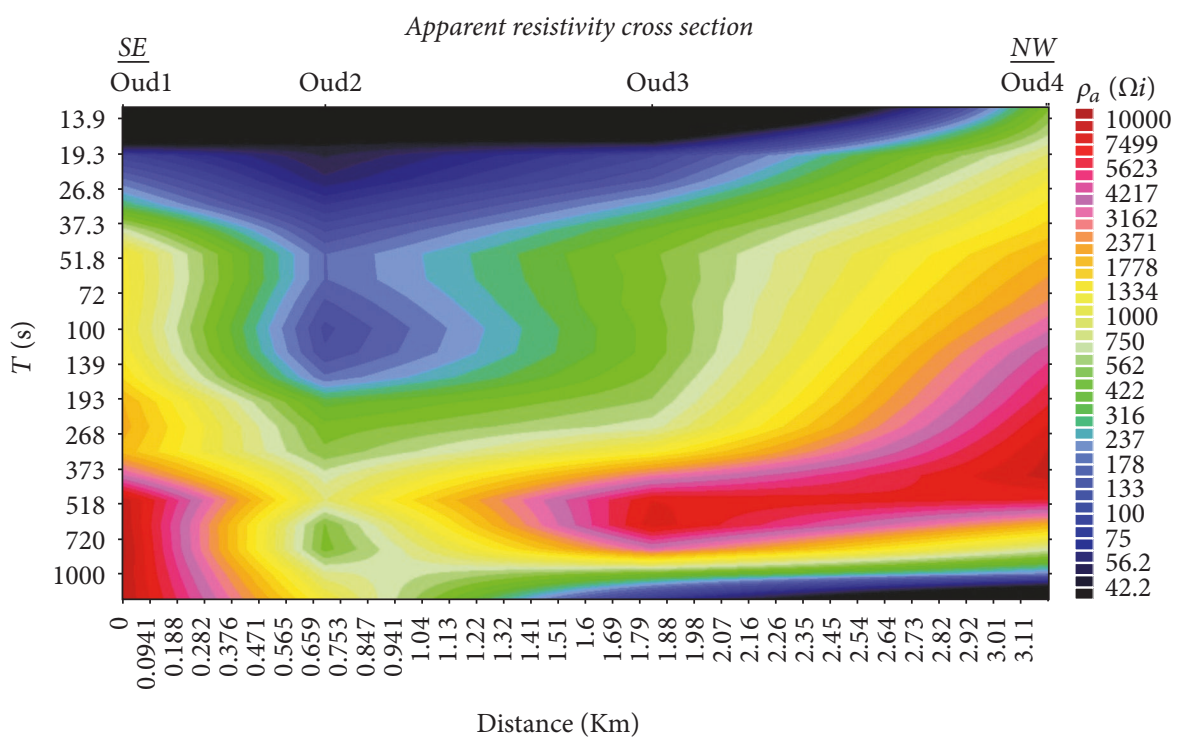

(a)

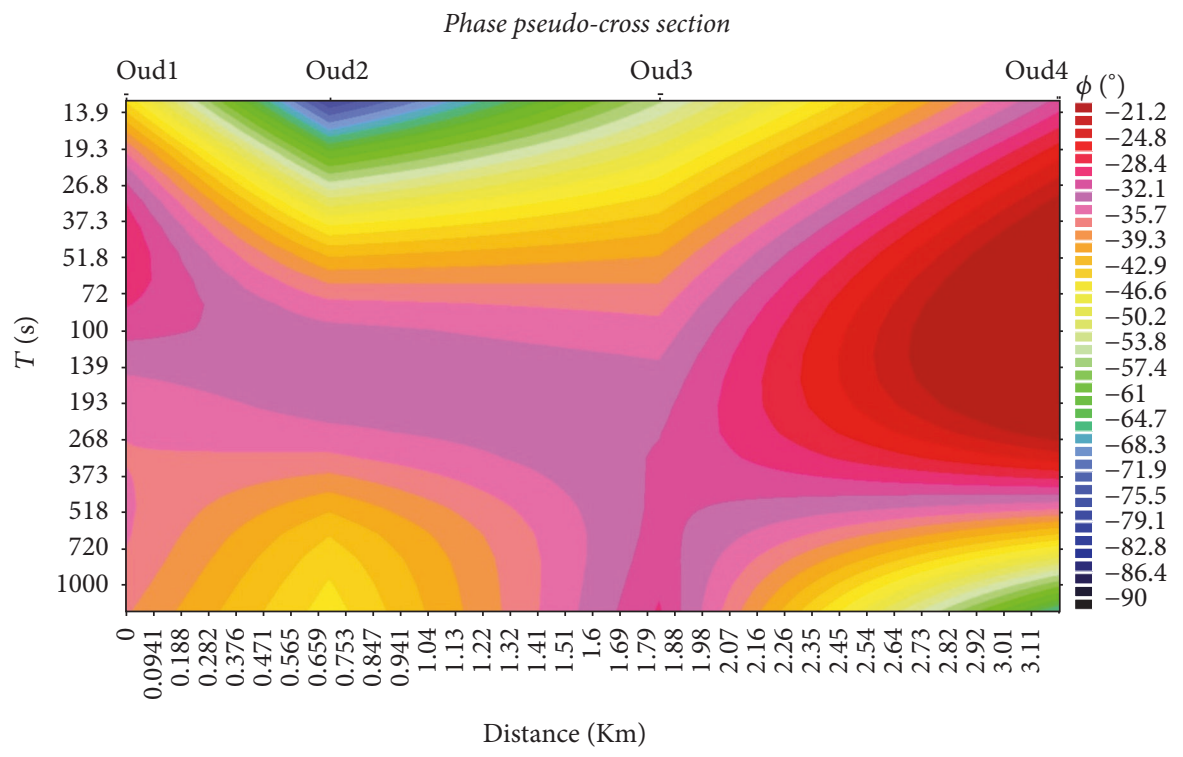

(b)

FIGURE 12: Apparent resistivity (a) and phase (b) pseudosection of Oudou profile.

These faults resulted from the deformation phases (D2 and D3) that have affected the study area. The results from previous geological studies $[1,35,36]$ strengthen the present results.

The analysis of the apparent resistivity profiles, pseudosections (apparent resistivity and phase), and geoelectrical sections from the three AMT profiles shows that the structures are well deformed by folded and fractured events that correspond to the Pan-African orogeny materialised by the SF and the BOSZ [3]

The investigated area is closer to the transition zone between the Pan-African and the Congo Craton domains. This is confirmed through the mixtures of conductive and resistive materials observed beneath the investigated area, suggesting a prolongation of the overlap between the Congo
Craton and the Pan-African in depth, to the north. Other studies confirm this overlapping $[10,12]$ and establish the $\mathrm{CC} /$ Pan-African limit above the northern $4^{\circ}$ parallel. However, studies were carried out (between latitudes $3^{\circ} 30 \mathrm{~N}$ and $\left.4^{\circ} 30 \mathrm{~N}\right)$ some distance away from the current study area (which stretches from latitudes $5^{\circ} \mathrm{N}$ to $5^{\circ} 30 \mathrm{~N}$ ); hence, we established that the CC/Pan-African limit in the area is located north beyond the known limit documented by [10, 12]. Investigations shall be carried out in the future to explain the shift between those two locations.

Geophysical investigation shows that the NW parts of the AMT profiles, which are located closer to the BOSZ, present resistive formations that are sometimes shallow close to the surface. In the SE part, these formations are also identified. This configuration would highlight a characteristic of the 


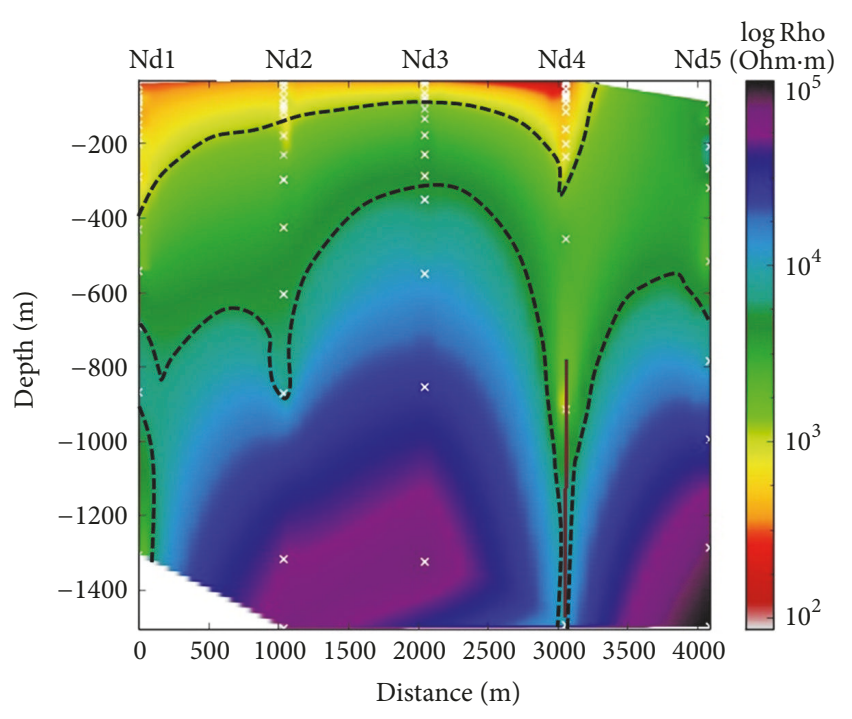

FIGURE 13: Geoelectrical section of Ndokayo profile at 1500 meters' depth.

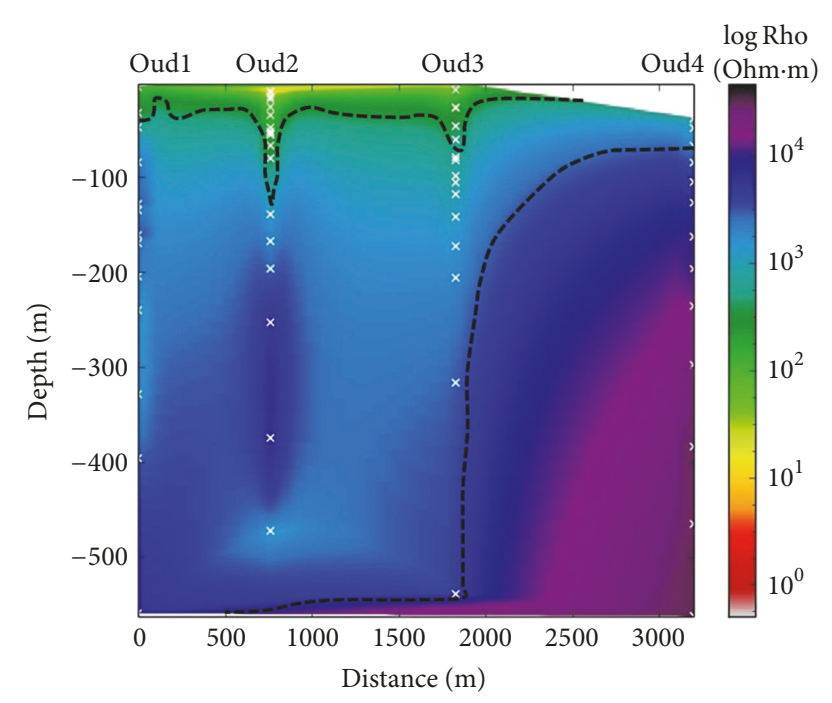

FIgURE 14: Geoelectrical section of Oudou profile at 600 meters' depth.

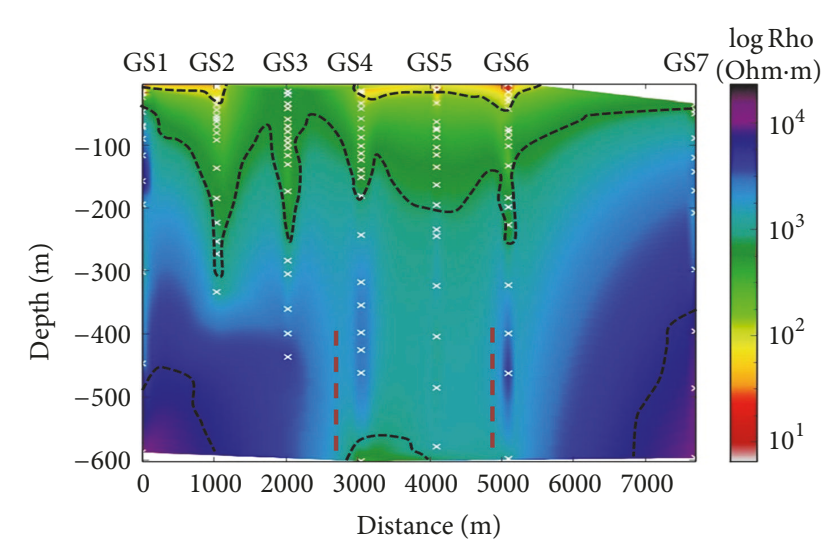

FIgURE 15: Geoelectrical section of Garga Sarali profile at 600 meters' depth.
BOSZ, which would be not only a shear zone but also a system of faults zone with raised and collapsed compartments.

The results obtained from the current study are of great importance in mining exploration. The geological investigation of the study area reported the presence of porphyritic plutonic rocks (granites) that were affected by contact metamorphism. The three AMT profiles (Ndokayo and Garga Sarali) display deeper discrete zones that are very conductive (Figure 13). These conductive areas may correspond to the presence of fluids, clay minerals, or metallic $(\mathrm{Cu}, \mathrm{Au}$, and $\mathrm{Ag})$ mineralized bodies.

The combination of geological facts and audiomagnetotellurics sounding analyses and modelling has led to the detection of electrical discontinuities. These electrical discontinuities oriented NE-SW are linked to the Central Cameroon Shear Zone [3]. The prolongation of these tectonic features has been revealed by recent geophysical studies carried out in adjacent areas $[11,12,37,38]$ in the southern and the northern borders of the area under study. Hence, there is a link between the present study and the previous ones, as it shows that the fault oriented NE-SW was derived from the tectonic event that has occurred during the Pan-African orogeny and it is directly aligned with the Central African Shear Zone (CASZ).

\section{Conclusion}

The integration of geophysical and geological data led to the following conclusions:

(i) The analysis, modelling, and interpretation of audiomagnetotellurics data show the existence of electrical discontinuities that could be interpreted as faults and which correlate with the surface structural lineaments trend evidenced by satellite imagery analysis.

(ii) The identified faults oriented NE-SW were linked to the Central Cameroon Shear Zone and linked to those discovered by recent studies using aeromagnetic and gravity interpretation, based on the multiscale horizontal derivative of the vertical derivative (MSHDVD) methods applied in adjacent areas situated in the northern and southern borders of the present study area.

(iii) The study area is made up of mixture of conductive (Pan-African) and resistive (Congo Craton) materials that suggest a prolongation of the overlap between the Congo Craton to the north and the location of the CC/Pan-African limit above N04 .

(iv) The fault system oriented NE-SW was formed by the tectonic event that occurred during the Pan-African orogeny and it is directly aligned with the Central African Shear Zone (CASZ).

(v) The structural dips on the geological map correspond to the orientation of electrical discontinuities.

(vi) The three AMT profiles (Ndokayo, Oudou, and Garga Sarali) show conductive anomalous zones that are distinct, running from the surface to great depth. These anomalies may correspond to the presence of 


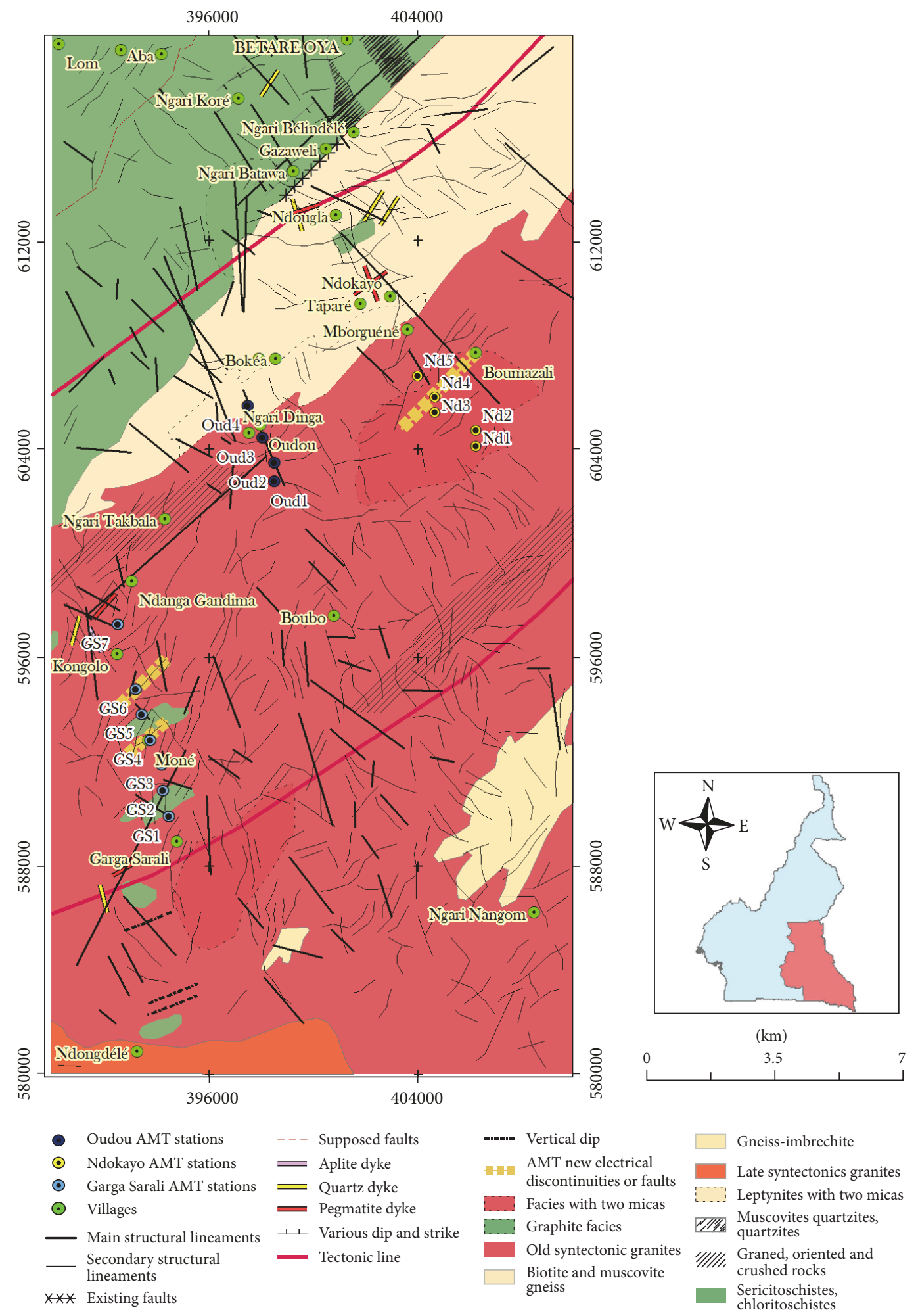

FIGURE 16: Correlation between surface structural lineaments and the new AMT electrical discontinuities (faults).

fluid, conductive clay minerals, or metallic mineralized bodies. (vii) The BOSZ is not only a shear zone but also a system of faults with raised and collapsed compartments. 


\section{Conflicts of Interest}

The authors declare that there are no conflicts of interest regarding the publication of this paper.

\section{Acknowledgments}

The authors are grateful to Mr. Ava Christophe, General Manager of Harvest Mining Corporation (HMC), for the logistics he provided to enable field works.

\section{References}

[1] B. Kankeu and R. O. Greiling, "Magnetic fabrics (AMS) and transpression in the Neoproterozoic basement of Eastern Cameroon (Garga-Sarali area)," Neues Jahrbuch fur Geologie und Palaontologie - Abhandlungen, vol. 239, no. 2, pp. 263-287, 2006.

[2] C. E. Suh, B. Lehmann, and G. T. Mafany, "Geology and geochemical aspects of lode gold mineralization at DimakoMboscorro, SE Cameroon," Geochemistry: Exploration, Environment, Analysis, vol. 6, no. 4, pp. 295-309, 2006.

[3] E. Njonfang, V. Ngako, C. Moreau, P. Affaton, and H. Diot, "Restraining bends in high temperature shear zones: The "Central Cameroon Shear Zone", Central Africa," Journal of African Earth Sciences, vol. 52, no. 1-2, pp. 9-20, 2008.

[4] S. Ganno, J. P. Nzenti, T. Ngnotue, B. Kankeu, and N. G. D. Kouankap, "Polyphase deformation and evidence for transpressive tectonics in the kimbi area, Northwestern Cameroon PanAfrican fold belt," Journal of Geology and Mining Research, vol. 2, no. 1, pp. 001-015, 2010.

[5] K. L. Zonge, A. G. Ostrander, and D. F. Emer, "Controlledsource audio-frequency magnetotelluric measurements," in Magnetotelluric methods: Soc. Expl. Geophys, K. Vozoff, Ed., Geophysics Reprint Series 5, pp. 749-763, 1986.

[6] S. K. Sandberg and G. W. Hohmann, "Controlled-source audiomagnetotellurics in geothermal exploration," Geophysics, vol. 47, no. 1, pp. 100-116, 1982.

[7] L. C. Bartel and R. D. Jacobson, "Results of a controlled-source audiofrequency magnetotelluric survey at the Puhimau thermal area, Kilauea Volcano, Hawaii," Geophysics, vol. 52, no. 5, pp. 665-677, 1987.

[8] T. Koichi, M. Enjang, J. Hisashi, M. Hideki, and U. Keisuke, "Imaging geothermal fractures by CSAMT method at takigami area in Japan," in Proceedings of the 13th Workshop on Geothermal Reservoir Engineering Stanford University, SGP-TR-176, Stanford, Calif, USA, January 2005.

[9] M. J. Unsworth, X. Lu, and M. Don Watts, "CSAMT exploration at Sellafield: Characterization of a potential radioactive waste disposal site," Geophysics, vol. 65, no. 4, pp. 1070-1079, 2017.

[10] B. Kelsey Mosley, E. A. Atekwana, M. G. Abdelsalam et al., "Geometry and faults tectonic activity of the Okavango Rift Zone, Botswana: Evidence from magnetotelluric and electrical resistivity tomography imaging," Journal of African Earth Sciences, vol. 65, pp. 61-71, 2012.

[11] T. Ndougsa-Mbarga, A. N. S. Feumoe, E. Manguelle-Dicoum, and J. D. Fairhead, "Aeromagnetic data interpretation to locate buried faults in south-east Cameroon," Geophysica, vol. 48, no. 1-2, pp. 49-63, 2012.

[12] A. Meying, T. Ndougsa-Mbarga, and E. Manguelle-Dicoum, "Evidence of fractures from the image of the subsurface in the
Akonolinga-Ayos area (Cameroon) by combining the Classical and the Bostick approaches in the interpretation of audiomagnetotelluric data," Journal of Geology and Mining Research, vol. 1, no. 8, pp. 159-171, 2009.

[13] Paterson G., Watson Ltd., Etude aéromagnétiques sur certaines régions de la République Unie du Cameroun. Rapport d'interprétation. A.C.D.I. Toronto, article 192, 1976.

[14] S. Mbom-Abane, Investigation géophysique en bordure du Craton $d u$ Congo (région d'Abong-Mbang/Akonolinga, Cameroun) et implications structurales. Thèse Doctorat d'Etat ès Sciences, Faculté des Sciences de l'Université de Yaoundé I, 1997.

[15] T. Ndougsa-Mbarga, E. Manguelle-Dicoum, C. T. Tabod, and S. Mbom-Abane, "Modélisation d'anomalies gravimétriques dans la région de Mengueme-Akonolinga (Cameroun)," Science, Technology and Development, vol. 10, pp. 67-74, 2003.

[16] V. Ngako, P. Affaton, J. M. Nnange, and T. Njanko, "Pan-African tectonic evolution in central and southern Cameroon: Transpression and transtension during sinistral shear movements," Journal of African Earth Sciences, vol. 36, no. 3, pp. 207-214, 2003.

[17] S. F. Toteu, W. R. Van Schmus, J. Penaye, and A. Michard, "New U-Pb and Sm-Nd data from north-central Cameroon and its bearing on the pre-Pan African history of Central Africa," Precambrian Research, vol. 108, no. 1-2, pp. 45-73, 2001.

[18] J. P. Nzenti, P. Barbey, J. M. Bertrand, and J. Macaudiere, "La chaîne pan-africaine au Cameroun : cherchons suture et modèle," in Proceedings of the Réunion des Sciences de la Terre in S.G.F., France, Nancy, France, 1994.

[19] J. P. Nzenti, P. Barbey, and F. M. Tchoua, "Evolution crustale au Cameroun : éléments pour un modèle géodynamique de l'orogenèse Néoprotérozoïque," in Géologie et environnements au Cameroun, J. P. Vicat and P. Bilong, Eds., collect. GEOCAM, 2/1999, pp. 397-407, University of Yaounde Press, 1998.

[20] T. Ngnotué, J. P. Nzenti, P. Barbey, and F. M. Tchoua, “The NtuiBetamba high-grade gneisses: A northward extension of the Pan-African Yaounde gneisses in Cameroon," Journal of African Earth Sciences, vol. 31, no. 2, pp. 369-381, 2000.

[21] J. Gazel and G. Gérard, "Carte géologique de reconnaissance du Cameroun au 1/500000 : coupure Batouri-Est avec une notice explicative," in Archives de la Direction des Mines et de la Géologie du Cameroun. Yaoundé, article 50, 1954.

[22] D. Soba, La série du Lom étude géologique et géochronologique d'un volcano-sédimentaire de la chaine panafricaine à l'Est du Cameroun. Thèse de doct. d'Etat (Univ. Pierre et Marie Curie Paris), 1989.

[23] L. Cagniard, "Basic theory of the magneto-telluric method of geophysical prospecting," Geophysics, vol. 18, no. 3, pp. 605-635, 1953.

[24] X. Garcia and A. G. Jones, "Atmospheric sources for audiomagnetotelluric (AMT) sounding," Geophysics, vol. 67, no. 2, pp. 448-458, 2002.

[25] K. Vozoff, "The magnetotelluric method in the exploration of sedimentary basins," Geophysics, vol. 37, no. 1, pp. 98-141, 1972.

[26] A. G. Jones, "On the Equivalence of the Niblett and Bostick transformation in the Magneto telluric Method," Geophysics, vol. 53, pp. 72-73, 1983.

[27] K. Vozoff, "The magnetotelluric method," in Electromagnetic Methods in Applied Geophysics, M. N. Nabighian, Ed., vol. 2, part B, p. 711, Society of Exploration Geophysicists, Tulsa, Olk, USA, 1991. 
[28] M. S. Zhdanov, "Magnetotelluric and magnetovariational methods," Geophysical Electromagnetic Theory and Methods, vol. 45, pp. 545-645, 2009.

[29] K. L. Zonge and L. J. Hughes, "Controlled source audiofrequency magnetotellurics," in Electromagnetic methods in applied geophysics, M. N. Nabighian, Ed., vol. 2, part B, pp. 448458, Society of Exploration Geophysicists, Tulsa, Okl, USA, 1991.

[30] E. Manguelle-Dicoum, A. S. Bokosah, and T. E. Kwende-Mbanwi, "Geophysical evidence for a major Precambrian schistgranite boundary in southern Cameroon," Tectonophysics, vol. 205, no. 4, pp. 437-446, 1992.

[31] M. A. Goldstein and D. W. Strangway, "Audio-frequency magnetotellurics with a grounded electric dipole source," Geophysics, vol. 40, no. 4, pp. 669-683, 1975.

[32] Geometrics, Operation manual for Stratagem systems running IMAGEM. ver. 2.16, Geometrics Printing Press, San Jose, Calif, USA, 2000.

[33] G. V. Keller, "Electrical properties," in Practical handbook of physical properties of rocks and minerals, R. S. Carmichael, Ed., pp. 359-427, CRC Press, Boca Raton, FL, USA, 1987.

[34] D. Eberhart-Phillips, W. D. Stanley, B. D. Rodriguez, and W. J. Lutter, "Surface seismic and electrical methods to detect fluids related to faulting," Journal of Geophysical Research: Atmospheres, vol. 100, no. B7, pp. 12,919-12,936, 1995.

[35] J. P. Nzenti, "Neoproterozoic alkaline meta-igneous rocks from the Pan-African North Equatorial Fold Belt (Yaounde, Cameroon): Biotitites and magnetite rich pyroxenites," Journal of African Earth Sciences, vol. 26, no. 1, pp. 37-47, 1998.

[36] B. Kankeu, R. O. Greiling, and J. P. Nzenti, "Pan-African strikeslip tectonics in eastern Cameroon-Magnetic fabrics (AMS) and structure in the Lom basin and its gneissic basement," Precambrian Research, vol. 174, no. 3-4, pp. 258-272, 2009.

[37] C. Noutchogwe Tatchum, C. T. Tabod, F. Koumetio, and E. Manguelle-Dicoum, "A gravity model study for differentiating vertical and dipping geological contacts with application to a bouguer gravity anomaly over the Foumban Shear Zone, Cameroon," Geophysica, vol. 47, no. 1-2, pp. 43-55, 2011.

[38] T. Ndougsa-Mbarga, A. Meying, D. Bisso, Y. Layu D, K. K. Sharma, and E. Manguelle-Dicoum, "Audiomagnetotellurics (AMT) soundings based on the Bostick approach and evidence of tectonic features along the northern edge of the Congo Craton, in the Messamena/Abong-Mbang area (Cameroon)," Journal of Indian Geophysical. Union, vol. 15, no. 3, pp. 145-159, 2011. 

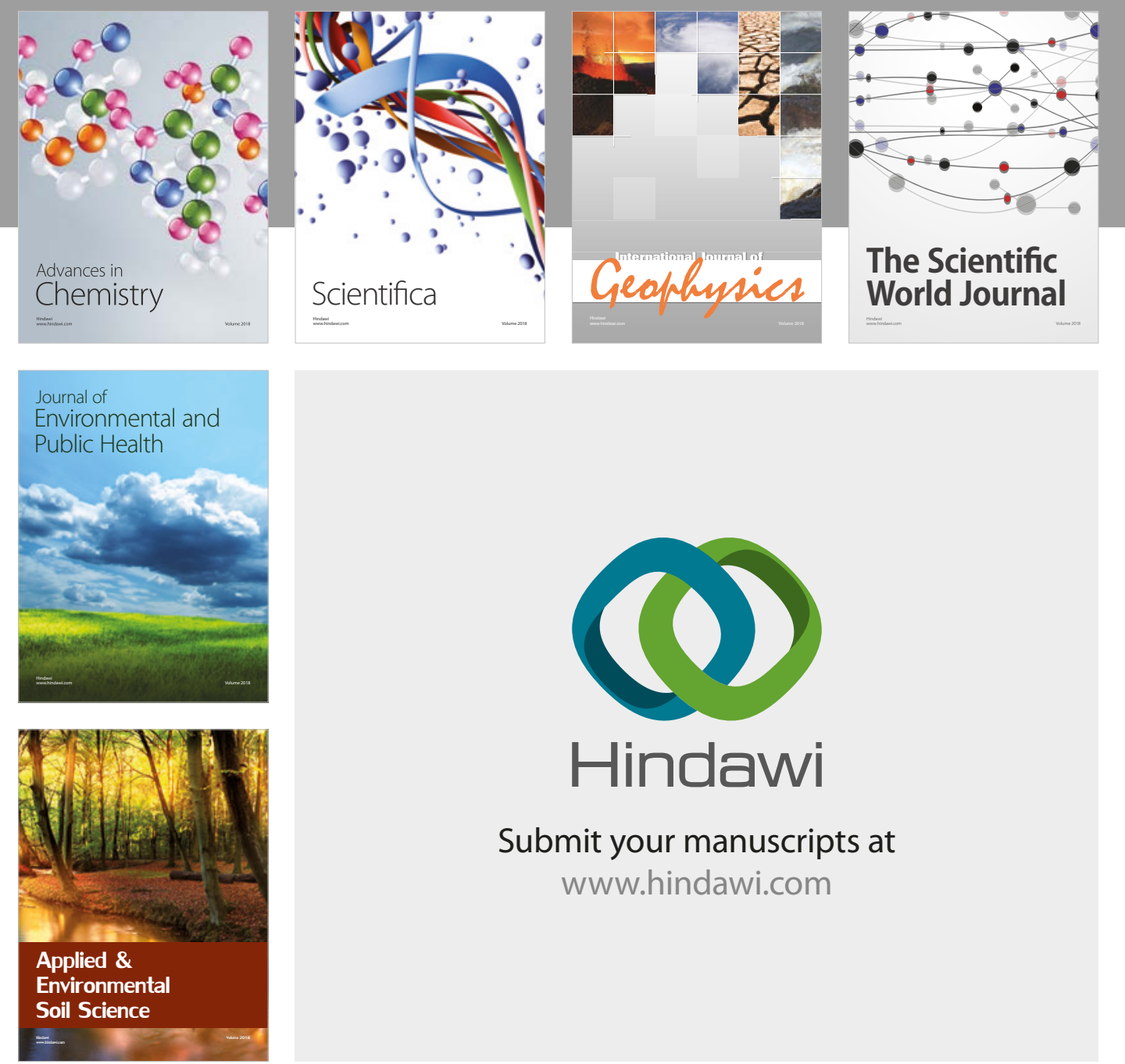

The Scientific

\section{World Journal}
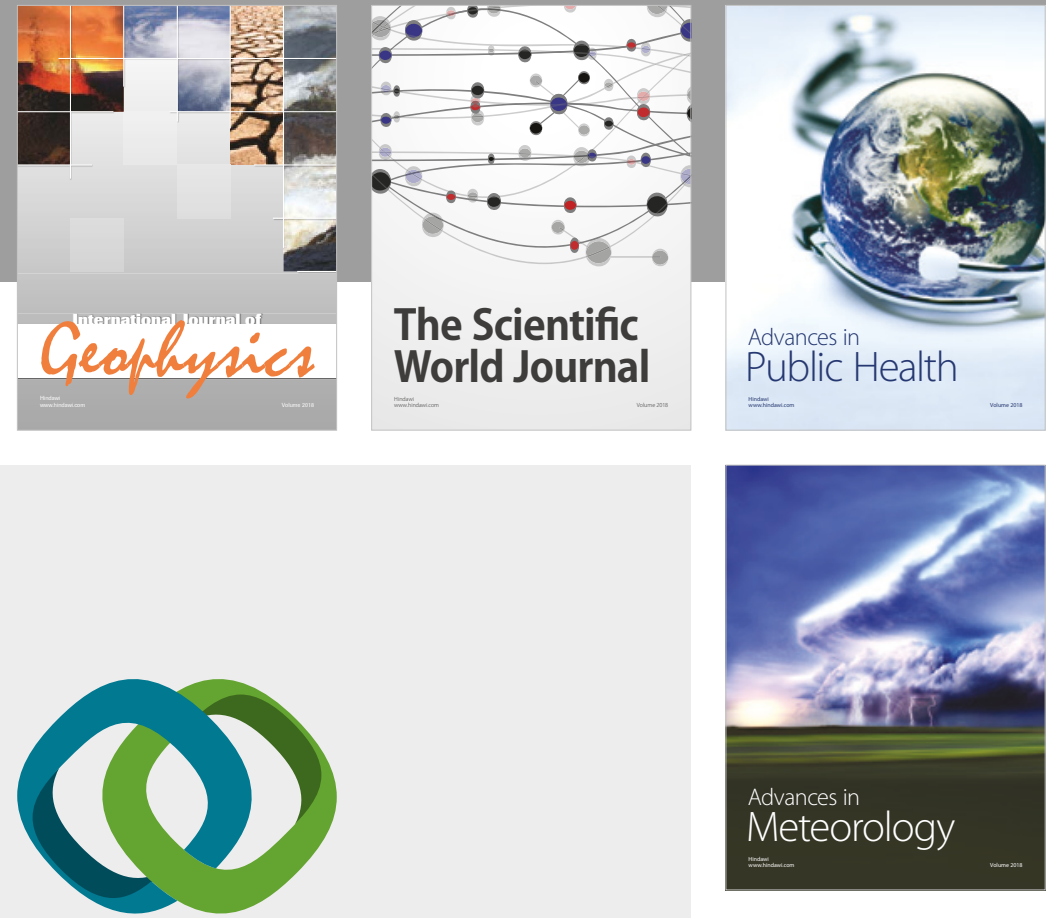

Advan

Public Health

\section{Hindawi}

Submit your manuscripts at

www.hindawi.com
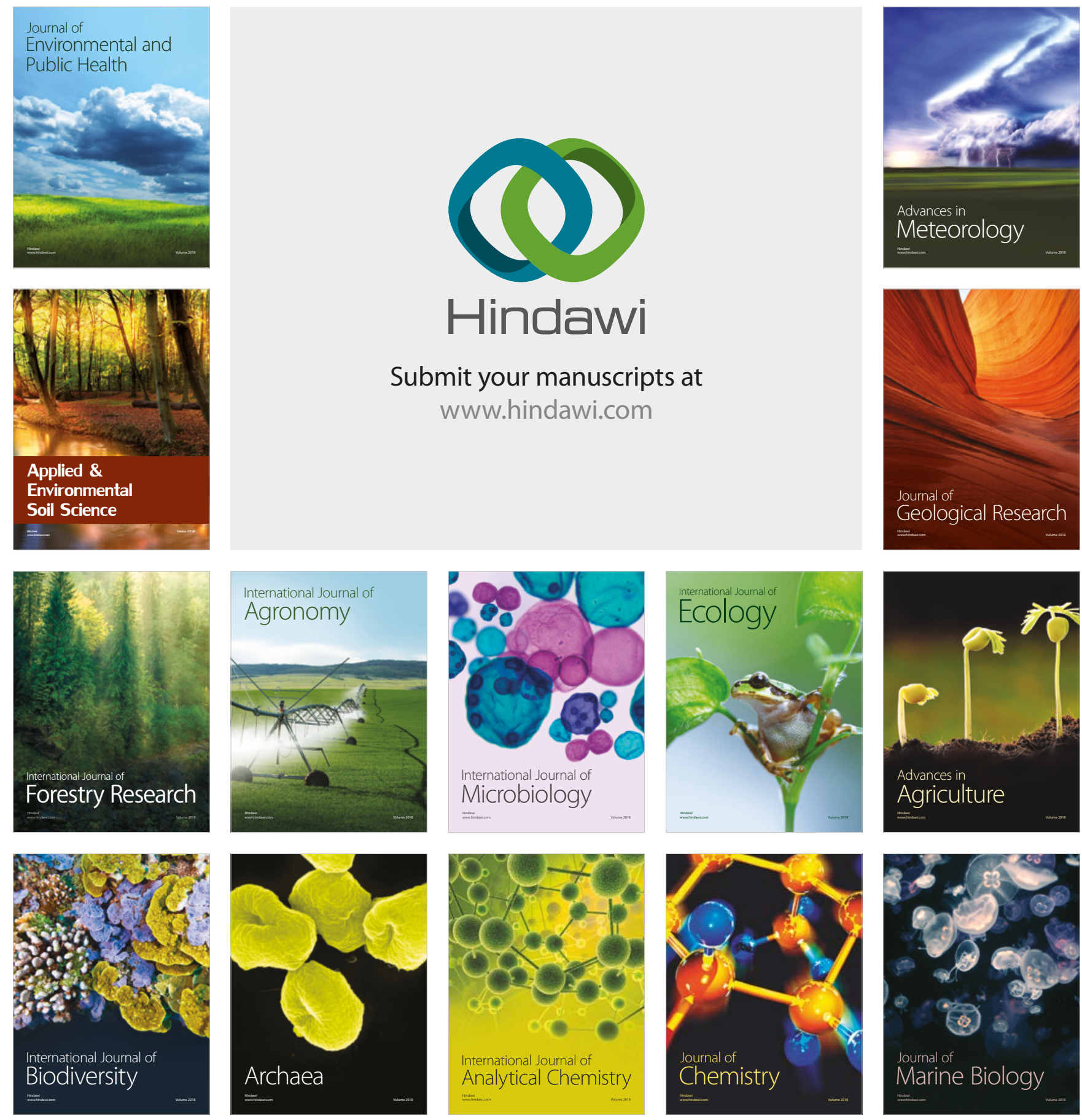